\title{
BIRD COMMUNITY STRUCTURE AND SPECIES RESPONSES TO EDGES IN LAUREL FOREST FRAGMENTED BY NARROW ROADS (TENERIFE, CANARY ISLANDS)
}

\author{
Juan D. Delgado*, Natalia Arroyo ${ }^{* *}$, José R. Arévalo ${ }^{* * *}$, \\ José María Fernández-Palacios
}

\begin{abstract}
We examined interacting effects of habitat structure, topographic landscape, road edge and vehicle traffic (density and noise), on bird species composition, abundance and diversity in the laurel forest of Tenerife (Canaries). We examined multivariate habitat and landscape factors determining bird community composition and structure, and modality of specific responses by comparing road edge vs interior zones. Abundance of breeding birds in laurel forest showed slight to no increases in response to roads. Two specialized taxa, the palaeoendemic pigeon Columba bollii and Regulus regulus, revealed neatest negative reductions in abundance near roads. Higher noise levels, vegetation density, lower canopy closure and wood selective extraction characterized roadsides. Most passerines showed moderate affinity for forest edges and did not evidence decreases due to road proximity. The topographic landscape in these mountainous areas strongly interacted with road edge effects to determine bird community structure. Narrow road disturbances on the laurel forest was related to moderate increase in bird abundance and diversity near edges, but at the cost of losing presence of forest-demanding species playing important ecological roles.
\end{abstract}

Keywords: Columba bollii, laurel forest, topographic landscape, bird modal responses, road impact.

\section{RESPUESTA DE LA ESTRUCTURA DE LA COMUNIDAD DE AVES Y LAS ESPECIES DE BOSQUES DE LAURISILVA FRAGMENTADOS A LA TRANSICIÓN CON CARRETERAS ESTRECHAS}

\section{RESUMEN}

Cuantificamos los efectos de la estructura del hábitat, la topografía, el efecto de borde viario y del tráfico de vehículos (intensidad de circulación y ruido) sobre la composición, abundancia y diversidad de aves en el bosque de laurisilva de Tenerife (Canarias). Modelizamos las respuestas de las aves comparando el borde con el interior forestal. La abundancia de aves nidificantes mostró una variación poco acusada en respuesta al efecto de borde, con dominancia de especies ampliamente tolerantes e incluso afines a estos ecotonos. Casi todos los paseriformes mostraron afinidad por los bordes viarios. Dos taxones especializados, la paloma paleoendémica Columba bollii y el pequeño paseriforme Regulus regulus, fueron menos abundantes en los bordes viarios. Los altos niveles de ruido, la mayor densidad de la vegetación, menor cobertura del dosel forestal y la extracción de madera fueron los principales factores de incidencia negativa sobre las palomas. El paisaje topográfico en estas áreas montañosas interactuó con esos efectos de borde e influyó en la estructura de la comunidad de aves. Las alteraciones del hábitat están relacionadas con un aumento de la abundancia y diversidad de la mayoría de especies orníticas en los márgenes, mientras que otros taxones importantes son menos frecuentes.

Palabras clave: Columba bolli, laurisilva, paisaje topográfico, respuesta modal de las áves, impacto de las carreteras.

DOI: https://doi.org/10.25145/j.SI.2021.04.06

Revista Scientia Insularum, 4; diciembre 2021, pp. 93-124; ISSN: e-2659-6644 


\section{INTRODUCTION}

Birds in road-fragmented forests face impacts from area reduction and ecosystem division, especially near urban, heavily disturbed areas (Yahner 1988, Bierregaard and Lovejoy 1989, Reijnen et al. 1995, Blair 1996, Canaday 1997). Changes in forest structure, microclimate and plant species composition may lead to population losses that may be critical for vulnerable, forest-dependent and endemic species, especially for those taxa relying on foraging and nesting places affected by habitat transformation (Bierregaard and Lovejoy 1989, Santos et al. 1998, Rolstad 1991, Maas et al. 2009).

Roads induce additional fragmentation by facilitating human access to formerly remote areas, producing changes in territorial uses, facilitating dispersal and transport of alien species, and by subsequent division of already separated remnants (Forman et al. 2002a, Donaldson and Bennet 2004, Coffin 2007, Fahrig and Rytwinski 2009, van der Ree et al. 2015). Bird species composition, abundance and diversity can be affected by roads in various ways, and these alterations may propagate large distances toward the preserved forest ionterior (Canaday 1997, Ortega and Capen 1999, Forman and Deblinger 2000, Forman et al. 2002a, b). Ecological gradients may favor edge-prone or habitat-generalist species whereas negatively impacting edge-avoiders or habitat-interior taxa (Lindell et al. 2007). Bird species richness decreases near highways and this effect propagates several kilometers into surrounding habitat (Brotons and Herrando 2001). Narrow forest roads can cause significant reductions in richness of area-sensitive bird species (or edge-avoiding taxa) (Laurance 2004, Laurance et al. 2004, Rich et al. 1994, Arévalo and Newhard 2011).

Road edges also induce high bird population densities, especially if birds are favored by habitat supplementation at these ecotones (Havlin 1987, Meunier $e t$ al. 1999, D’Amico et al. 2013). Habitat quality in road-fragmented forests determines bird density and use of space for nesting and feeding (Reijnen and Foppen 1994, Willson et al. 1994, Kociolek et al. 2011). Śálek et al. (2010) found that bird richness decreased from forest edges, to low traffic road edges, to forest interior in central Europe. Forest road margins provide complementary resources that are unavailable at forest interior (Yahner 1988). However, this habitat use may involve other risks. For example, Holm and Laursen (2011) found that Great tit Parus major broods

* Área de Ecología, Dept. Sistemas Físicos, Químicos y Naturales, Universidad Pablo de Olavide, E-41013, Ctra. de Utrera Km. 1, Sevilla, Spain. E-mail: jddelgar@upo.es.

** Department of Applied Economics, Universidad de La Laguna, Tenerife, Canary Islands, Spain.

*** Department of Botany, Ecology and Vegetal Physiology, Universidad de La Laguna, Tenerife, Canary Islands, Spain.

- Island Ecology and Biogeography Research Group, Inst. Universitario de Enfermedades Tropicales y Salud Pública de Canarias (IUETSPC), Universidad de La Laguna, Tenerife, Canary Islands, Spain. 
suffered greater mortality in hedgerows near roads with dense and high-speed traffic than in others of lower intensity or without any traffic.

So far, road impacts on birds have been studied mostly in continental areas of the Northern hemisphere. Road disturbances to oceanic island birds are much less studied (Delgado et al. 2008). A particularly poorly studied aspect is the roadkill incidence from traffic on animal populations on oceanic islands, particularly on birds and mammals (Tejera et al. 2018). For instance, bird roadkill in the Lanzarote Biosphere Reserve has been found to be high even under relatively low traffic intensity (Tejera et al. 2018). Fragmentation processes other than roads are also known to induce severe declines in island bird species (Castelleta et al. 2005, García-del-Rey et al. 2013).

Roads have increased in area and extended their effects in spatially-limited island ecosystems over the last few decades. However, their effects on oceanic island biotas are still poorly known. Most bird extinctions have been reported from oceanic islands (Steadman 2006). The role of human transport corridors in this demise is not well understood for oceanic islands. Other causes of threatening, like hunting or alien predators may interact with a developed road net to augment impact on native avifaunas on islands (Whittaker and Fernández-Palacios 2007, García-Carrasco et al. 2020). Ecological impacts of roads traversing orographically complex landscapes such as mountain forests on islands are scarcely studied (Gucinski et al. 2001). On oceanic islands and mainland mountain habitats, orography may greatly determine impacts of road fragmentation and ecological responses of birds (McGarigal and McComb 1995, Miller et al. 1996).

The Canarian laurel forest (or laurisilva) is a Tertiary-relict, subtropical ecosystem, which harbors exclusive bird taxa, partly due to insular conditions, as well as Palearctic elements (Báez 1992, Martín and Lorenzo 2001). These island bird assemblages are relatively poor in species diversity, forming simple communities if compared to nearest continental grounds (Iberia, North Africa). However, the laurisilva shelters interesting populations of palaeoendemic frugivore pigeons and several subspecific endemic passerines, internationally relevant, deserving efforts in basic and applied research, and which interact with the landscape structure and impacts derived from roads traversing these forests.

Apart from birds, diverse road edge effects on other biotic and abiotic aspects of the laurisilva, conferring forest interior-edge contrast which in turn may interact and affect birds have been already reported (Delgado et al. 2001, 2007a,b, 2013a,b). Furthermore, in a previous study comparing bird communities near road edges and at forest interior, we found a weak dependence of bird abundance on road proximity (Delgado et al. 2008). Road edge effects on birds may be obscured by or interact with other concurrent habitat factors such as landscape configuration and vegetation structure. Hence, there is a need to disentangle those factors likely explaining the observed pattern of bird species abundance in this road-fragmentation context. We thus performed a multifactorial approach to bird species responses to roads as linear elements integrated in the forest landscape, considering both vegetation structure and diversity and landscape type.

We aimed to answer the following questions: Does road proximity affect breeding bird community structure, i.e. in terms of abundance, species composition, 
diversity, and species-specific abundance responses? We compared forest structure (habitat types and vegetation) between road edges and forest interior to assess how the bird community responds to such variation. We aimed to classify bird species regarding their responses to forest structure and road proximity. Finally, distance between natural areas and the suburban zone determines human accessibility by car, and the intensity of direct and indirect road disturbances (traffic, noise, human presence) reaching remote patches. Hence, we also aimed to assess the extent of impact on the bird species abundances along a gradient of motorized traffic and noise.

\section{MATERIAL AND METHODS}

\section{STUdY AREA}

Here we realized bird censuses along asphalt roads and at forest interior of the laurisilva in the Anaga mountains, the largest laurisilva remnants on NE Tenerife, Canaries $\left(28-29^{\circ} \mathrm{N}, 16-17^{\circ} \mathrm{W}\right)$ (fig. 1, table 1). We performed censuses in both mature laurisilva (mainly formed by Laurus novocanariensis, Morella faya, Ilex canariensis, Erica arborea, Persea indica, Prunus lusitanica and Apollonias barbujana) and Erica-Morella formations (tree-heath-wax-myrtle thicket) (del Arco et al. 2010). These forests are traversed by a narrow, two-lane asphalt road mostly running along the ridge and steep ravine slopes of the massif dorsal, connecting sparse settlements by a set of minor secondary roads (fig. 1, table 1). We divided the census zones following the gradient of increasing distance from the periurban area (W of the study forest, Las Mercedes), toward the easternmost sector of Anaga (table 1). Due to road width, high frequency of curves and asphalt surface conservation and remoteness, the motorized traffic losses intensity, and human disturbance decreases along the road from W to E. General features of structure, composition and diversity of the study forests have been exposed in detail elsewhere (Delgado et al. 2008, Delgado 2009, Fernández-Palacios 2009).

To assess the magnitude of the gradient in traffic density between suburban and remote areas, we noted number of vehicles per hour, at every sampling point along bird count transects (table 1). We also used official traffic density data (Mean Daily Intensity, MDI; Cabildo de Tenerife 2001). To obtain a general view of motorized traffic in the study area, we used data from 5 gauging measuring stations to check for MDIs for years 2002 (that of this study), 2008, 2013 and 2017 (last year with available traffic data) (Cabildo de Tenerife, 2018). MDIs averaged 1311.3 vehicles/ day $(708.23, \mathrm{SD})$ for the whole period; no significant differences in traffic intensity were found between years by means of a chi-square test $\left(\chi_{3}^{2}=1.544, p>0.05\right)$.

\section{BIRD COUNTS}

We performed bird counts between april-june, 2002, encompassing the breeding season for most species (Martín and Lorenzo 2001). Censuses started early in the morning (07:00-08:00 am) and lasted for 3-4 hours depending on weather. 


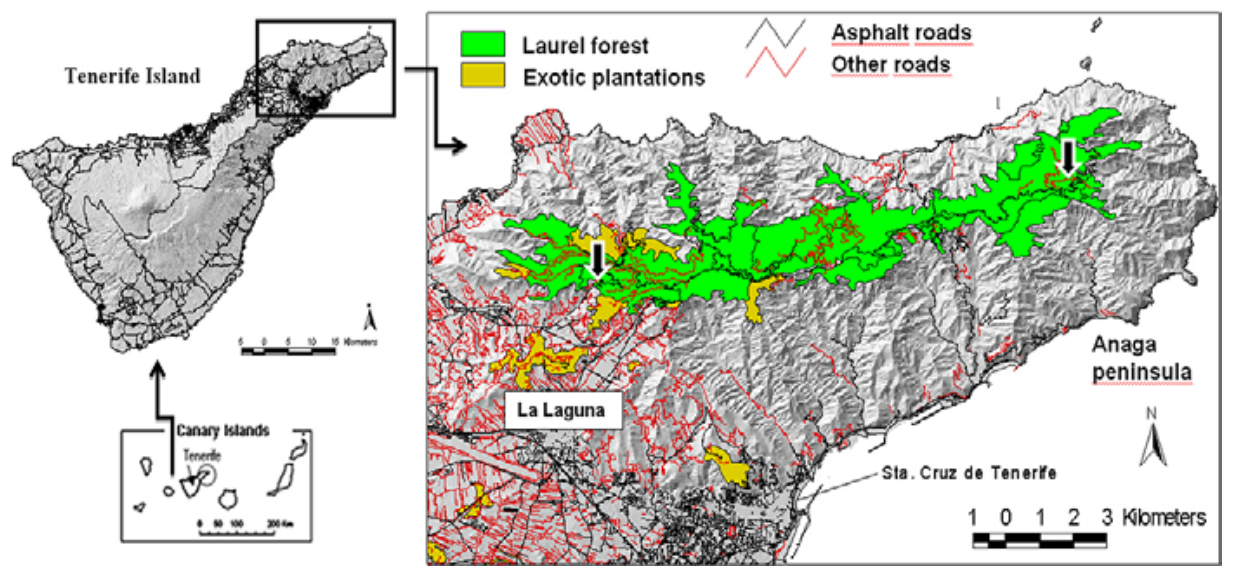

Figure 1. Map of the study area in eastern Tenerife (Canary Islands) showing the road-remoteness gradient along the Anaga peninsula. The black arrows represent the extremes of the gradient along the road transect (enclosed within the laurel forest tract longitudinally arranged along the peninsula) between the periurban area near La Laguna city (West) and the farthest road end (East). The concentrations of urban and periurban areas and vial infrastructure are depicted by the line pattern (asphalt and other roads).

We perform census only in absence of windy or rainy weather and relatively calm weather conditions.

We used linear transects which were subdivided into replicates with a fixed band of $50 \mathrm{~m}$ width (Bibby et al. 2000). Each complete transect was replicated three times, yielding a total of 36 count sessions distributed in 12 major transect units (table1), changing the order of transects between census days. We distributed transects and transect length between road edges and forest interior as homogeneously as possible according to area and topography limitations of this forest ecosystem. Forest interior was defined as areas distant $\geq 100 \mathrm{~m}$ from any transport or urban infrastructure, human-made clearings or forest-shrubland ecotones. We chose this distance because of the frequency and density with which in these forests there appear paths and dust tracks interrupting transects longer than such distance. We aimed to avoid influence of proximity of such linear gaps to our focal linear infrastructures. Many studies have shown that road influence reaches far into the traversed habitats (review in Forman et al. 2002). However, in our study area there were a higher chance of intersection with other interposed linear structures such as firebreaks, paths and roads, and other forest edges within the first $100 \mathrm{~m}$ from our focal road (Delgado et al. 2007, 2008). Hence, forest interior was defined as areas distant $\geq 100 \mathrm{~m}$ from any transport or urban infrastructure, human-made clearings or forest-shrubland ecotones.

We subdivided each transect in $100 \times 50 \mathrm{~m}(0.5 \mathrm{ha})$ subunits to take bird data and traffic noise. The overall census effort was 72 and 113 sampling subunits along road edges and interior forest respectively (table 1). Different sampling size 


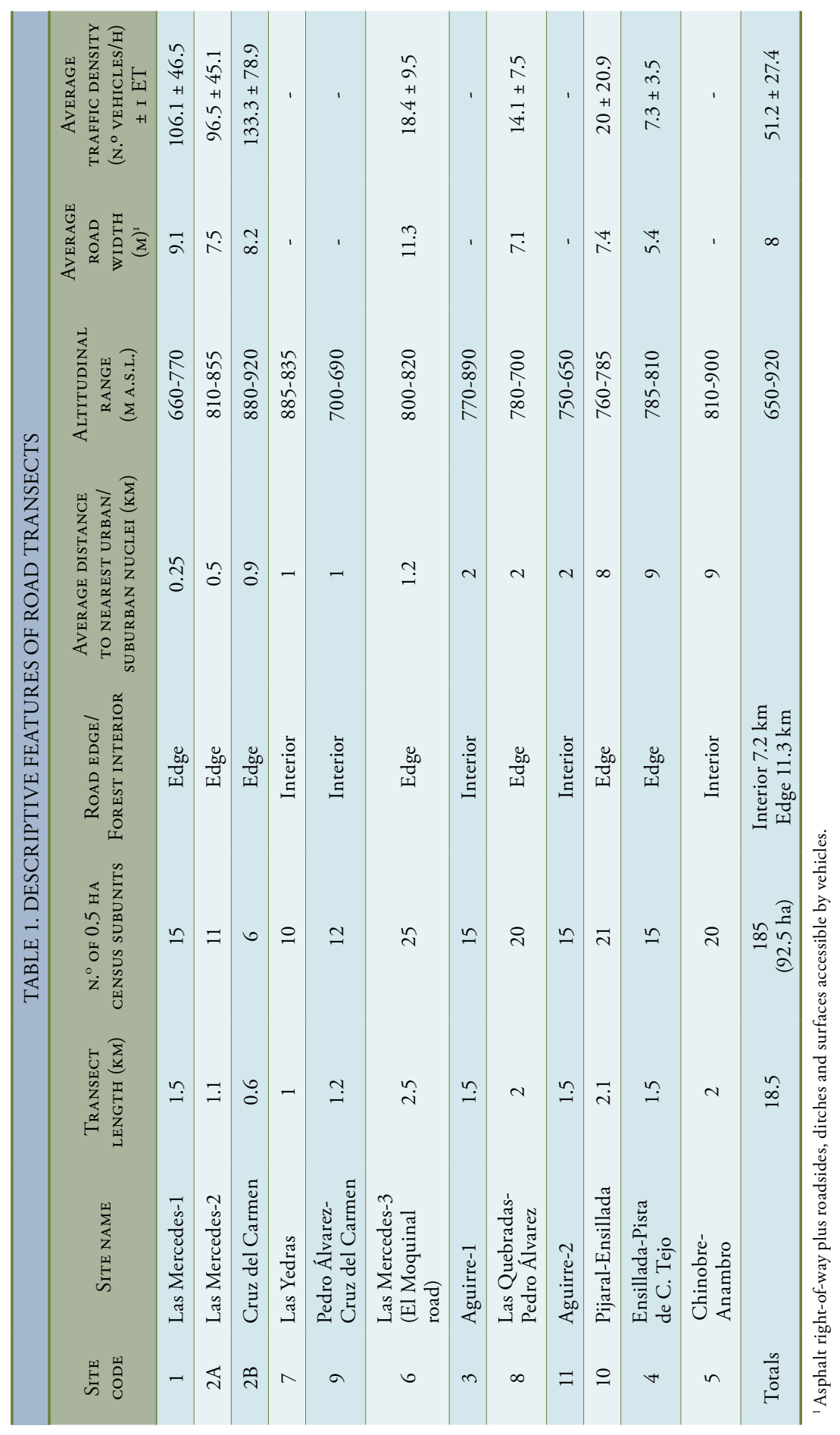


for forest edge and interior is due to limitations of accessibility and on-road safety in abrupt terrain. We also established these census subunits to facilitate collection of sound, habitat and vegetation data in order to relate these attributes with bird variables (see below).

\section{NOISE AND TRAFFIC DENSITY}

Noise recording was performed by a person walking ca. 10-20 $\mathrm{m}$ behind the bird observer (J.D. Delgado), along with bird census from 07:00-08:00 $\mathrm{h}$ and during 3-4 hours. Noise level samples were taken along roads and at forest interior. Roads were walked along the asphalt edge; interior forest was subdivided in $100-\mathrm{m}$ long transect subunits running further than $100 \mathrm{~m}$ from the edge. At the start and the end of each subunit, we took three consecutive 1-min noise samples (3 minutes per sampling point) (Harris 1998). We recorded noise with a handheld YF-22, Type 2 sound level meter. Measures were taken within the frequency range $31.5 \mathrm{~Hz}-8 \mathrm{KHz}$. Bird vocalizations are mostly produced within the $2-4 \mathrm{KHz}$ range (Dooling and Popper 2007, Wright et al. 2010). This means that any non-wanted sound within this frequency will have the highest probability to mask bird sounds and affect song perception through changes in the sound environment of birds. Noise intensity was adjusted to the range 20-130 decibels $(\mathrm{dB}(\mathrm{A}))$, weighed logarithmic measure $\mathrm{A}$, or A-weighting (Harris 1998). We used this procedure because the A-weighting mode for decibels is the most commonly used method in bird studies. A-weighting is useful to estimate overall sound pressure in a mode which maximizes similarity with bird hearing range, taking into account that there also differences between bird species and habitat structure (Dooling and Popper 2007, Wright et al. 2010). Resolution was $0.1 \mathrm{~dB}(\mathrm{~A})$ and precision $\pm 1.5 \mathrm{~dB}(\mathrm{~A})$. The sound level meter was used in LmaxLmin mode held at $-1.3 \mathrm{~m}$ above ground (probe directed to the opposite edge; the same road edge was always sampled). Minimum, maximum and average values were obtained for each 1-min sample and 3 min overall. As a noise level indicator we used a sound pressure level or energy equivalent level (Leq; Harris 1998). For a measurement period of $1 \mathrm{~min}$, Leq expresses a continuous-value signal having the same total energy than the single sound recordings. In other words, it represents, for birds being affected by traffic noise, the level or pressure of noise which equals the energy average of sequential individual measurements taken over a sampling period. The following equation (Harris 1998) was computed:

$$
L e q=10 \log _{10}\left[1 / \mathrm{T} \sum \mathrm{t}_{\mathrm{i}} \cdot 10^{\mathrm{Li} / 10}\right][\mathrm{dB}(\mathrm{A})]
$$

where

$\mathrm{T}=$ recording time during which the noise level is: $\mathrm{Li} \pm 2[\mathrm{~dB}(\mathrm{~A})]$

$\mathrm{Li}=$ single sound record (i) $[\mathrm{dB}(\mathrm{A})]$

$t_{i}=$ time duration of each single sound record 


\begin{tabular}{|c|c|c|}
\hline VARIABLE & Code & Details \\
\hline \multicolumn{3}{|l|}{ Road and other landscape attributes } \\
\hline 1) Total width (m) & RW & $\begin{array}{l}\text { Asphalt surfaces }+ \text { accessible roadsides } \\
\text { (with graduated tape) }\end{array}$ \\
\hline 2) Verge (side) width (m) & SW & On both sides of the asphalt surface \\
\hline 3) Average slope (o) & Slope & With hand clinometer \\
\hline $\begin{array}{l}\text { 4) Topographic category (ridge, slope, } \\
\text { valley) }\end{array}$ & Topo & \\
\hline \multicolumn{3}{|l|}{ Vegetation and substrate attributes ${ }^{1}$} \\
\hline \multicolumn{3}{|l|}{ Vegetation } \\
\hline 5) Tree canopy cover $(\%)^{2}$ & CCover & $\begin{array}{l}\text { With spherical forest densiometer } \\
\text { (Lemmon, 1957). }\end{array}$ \\
\hline 6) Average canopy height (m) & CHeight & \\
\hline 7) Understory shrub cover (\%) & ShrubCov & \\
\hline 8) Average shrub height (m) & ShrubHe & \\
\hline 9) Herb/grass cover (\%) & GrassCov & \\
\hline $\begin{array}{l}\text { 10) Stem (trunk) density (diameter } \\
\left.\text { classes }^{3} \text {, in } \mathrm{cm}\right):<5 ; 5-10 ; 10-20 \text {; } \\
20-30 ;>30\end{array}$ & $\begin{array}{l}\text { T5, T10, T20, } \\
\text { T30, Tm } 30\end{array}$ & \\
\hline 11) N. ${ }^{o}$ vertical vegetation strata ${ }^{4}$ & NStra & \\
\hline $\begin{array}{l}\text { 12) N. } .^{\circ} \text { fleshy-fruit producing plant } \\
\text { species }\end{array}$ & FruitSpp & \\
\hline 13) N. ${ }^{\circ}$ shrub species & ShrubSpp & \\
\hline 14) N. ${ }^{\circ}$ tree canopy species & TreeSpp & \\
\hline $\begin{array}{l}\text { 15) N. }{ }^{\circ} \text { stumps of woody plant species } \\
\text { (selective logging) }\end{array}$ & Stump & \\
\hline \multicolumn{3}{|l|}{ Ground or substrate } \\
\hline 16) Litter cover (\%) & LittCov & \\
\hline 17) Rocky cover $(\%)$ & RockCov & \\
\hline \multicolumn{3}{|c|}{$\begin{array}{l}1 \text { Variables taken within } 10 \mathrm{~m} \text {-radius circles; all visual counts and visual estimates unless } \\
{ }^{2} \text { Along road transects tree canopy cover was recorded directly above the corridor cente } \\
\text { toward the forest. } \\
{ }^{3} \text { Diameter at breast height (DBH). } \\
{ }^{4} \text { Number of vegetation strata between ground level and canopy above the circle center. }\end{array}$} \\
\hline
\end{tabular}

\section{Habitat STRUCture ASSESSMENT}

We surveyed habitat structure to analyze its correlations with bird community patterns along road edges and forest interior. Two habitat surveying points were set at the beginning and the end of each $100 \mathrm{~m}$ transect subunits $(\mathrm{n}=370$ points overall). Each point was a circle (radius: $10 \mathrm{~m} ; 314.2 \mathrm{~m}^{2}=0.031 \mathrm{ha}$ ) within which habitat variables were estimated (table 2). The pooled area of the 2 points 
(0.062 ha) covered $-12 \%$ of transect area $(0.5 \mathrm{ha})$. We recorded general landscape features and local habitat variables to explore their influence on bird community structure: a) road width, and b) width of both road edges combined (since birds often use such edges for foraging), c) terrain slope, d) three topographic categories (ridge, slope or hillside, and valley bottom or ravine basin) to determine if topography affects other structural variables (Miller et al. 1996); e) eleven descriptors of structure and composition of vegetation, and two descriptors of ground substrate at the plot scale (table 2).

\section{STATISTICAL ANALYSIS}

We estimated differences between road edge and forest interior in composition, species richness, Shannon's diversity $\left(\mathrm{H}^{\prime}=-\sum p_{i} \ln p_{\text {; }}\right.$; where $p_{i}$ is the frequency of species $i$ in relation to total number of individuals in a sample of $n$ species), equitativity or evenness $\left(E=H^{\prime} / H_{\text {max }}^{\prime}\right.$, where $\left.\mathrm{H}_{\max }^{\prime}=\ln S\right)$, Simpson's dominance index $\left(\mathrm{D}=1 / \sum p_{i}^{2}\right)$, and bird density ( $\mathrm{n}^{\circ}$ birds/10 ha) (Magurran 2004). Between (edge vs. interior) and among (ridge, slope, valley) habitat categories in community descriptors were tested for significance by the Kruskal-Wallis and MannWhitney's U tests (Sokal and Rohlf 1995).

Associations between distance to suburban edge, traffic density and noise levels, and the parameters of the bird community were assessed by non-parametric correlation (Spearman's Rho, r). To test the relationship between our two problem variables, namely noise levels (independent variable) and bird abundances (dependent variable), partial correlation analysis was used as an additional way to control for the influence of road edge proximity, and distance to suburban edge. We aimed to ascertain that any potential bird-noise relationship were not due to their association with transect location regarding road edges, or transect proximity to urban areas. We thus fixed the effect of transect location (road edge vs. forest interior), and transect distance in $\mathrm{km}$ to the nearest urban or suburban nuclei. We performed these analyses in SPSS (SPSS 1999).

To explore the structure of the bird community, both species and subunits were ordinated by means of a detrended correspondence analysis (DCA, a unimodal, indirect gradient analysis; Hill and Gauch 1980, ter Braak and Smilauer 1998). A weighting factor was assigned to species depending on their relative abundance. By canonical correspondence analysis (CCA) we analyzed the species-habitat interactions within a context of road proximity (ter Braak and Smilauer 1998, Pearman 2002). Goodness- of-fit for variables exerting significant effects on bird abundance was assessed by Monte Carlo permutation tests with 500 randomizations. Previously to the ordination, we identified redundant environmental information by exploring the relationships within our variable pool through factor analysis (Principal Components Analysis, PCA, Gauch 1982). We followed the Kaiser-Meyer-Olkin adequacy test $(\mathrm{KMO} \geq 7)$, sphericity test $(\mathrm{p}<0.05)$, selecting eigenvalues $>1$ and Varimax rotation of the analytical solution. 


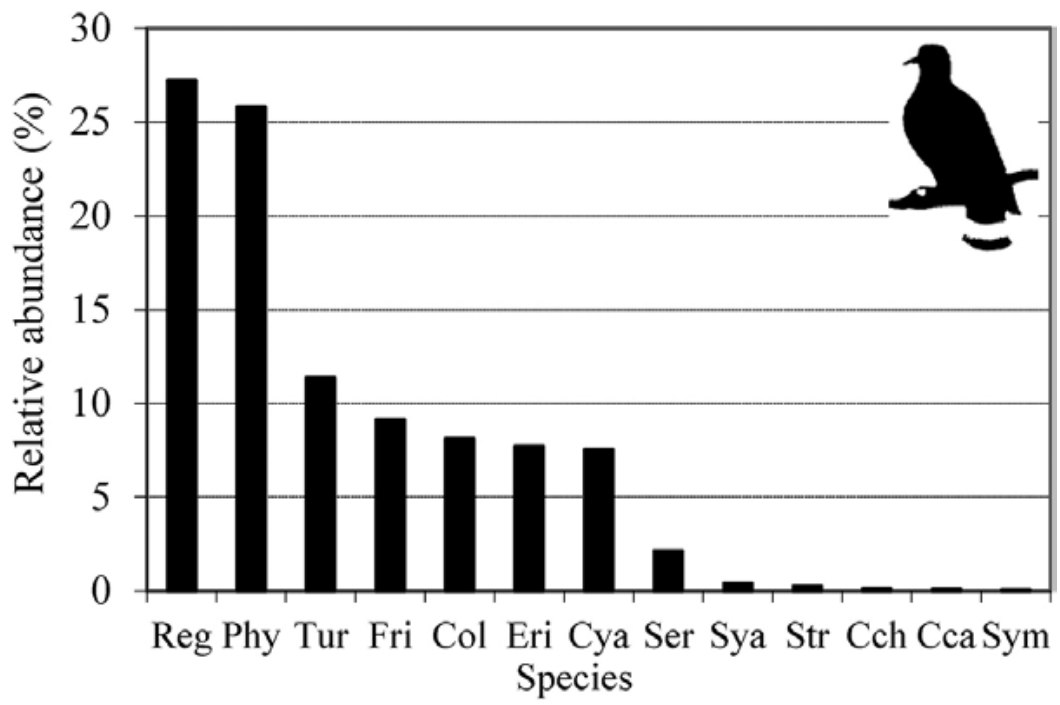

Figure 2. Composition and distribution of relative abundance of laurisilva birds in the breeding season (road and interior data combined). Species codes: Cca: Carduelis carduelis; Cch: Carduelis chloris; Col: Columba bollii; Eri: Erithacus rubecula; Fri: Fringilla coelebs; Cya: Cyanistes teneriffae; Phy: Phylloscopus canariensis; Reg: Regulus regulus; Ser: Serinus canarius; Str: Streptopelia turtur; Sya: Sylvia atricapilla; Sym: Sylvia melanocephala; Tur: Turdus merula.

The responses in population density to roads were analyzed for each species by locally weighted regression scatterplot smoothing (LOWESS, Cleveland et al. 1992). With this we aimed to explore the shape and strength of the association between bird species density and habitat structure. We thus adjusted the best available function to successive pairs of data, without assuming a linear relationship between dependent (bird density) and independent (habitat) variables. For DCA, CCA and LOWESS analysis we used CANOCO v. 4.5 (ter Braak and Smilauer 1998).

\section{RESULTS}

\section{BIRD COMMUNITY COMPOSITION AND STRUCTURE}

We recorded a total of 13 bird species, 11 passeriformes and 2 columbiformes (fig. 2). The community was dominated by two small passerines, Regulus regulus and Phylloscopus canariensis, which made ca. 53\% of the bird assemblage (fig. 2, table 3). The other quantitatively important species were Turdus merula, Fringilla coelebs, Columba bollii, Erithacus rubecula, Cyanistes teneriffae and, in smaller numbers, Serinus canaria, Sylvia atricapilla and Streptopelia turtur. 


\begin{tabular}{|c|c|c|c|}
\hline \multicolumn{4}{|c|}{$\begin{array}{l}\text { TABLE 3. DENSITY (BIRDS/10 HA, MEAN } \pm 1 \text { STANDARD DEVIATION, SD), } \\
\text { FOR THE THREE CENSUS REPLICATES COMBINED. SHOWN IS THE SPECIES } \\
\text { FREQUENCY (N. }{ }^{\circ} \text { OF } 0.5 \text { HA SUBUNITS WITH A SPECIES PRESENCE N=185 } \times 3=555 \\
\text { SAMPLES) AND RELATIVE ABUNDANCE IN THE COMMUNITY }(\%)\end{array}$} \\
\hline Species & Density & FREQUENCY & $\%$ \\
\hline Regulus regulus & $29.9 \pm 23.79$ & 374 & 27.21 \\
\hline Phylloscopus canariensis & $28.4 \pm 21.89$ & 391 & 25.80 \\
\hline Turdus merula & $12.5 \pm 16.69$ & 223 & 11.37 \\
\hline Fringilla coelebs & $10 \pm 17.47$ & 161 & 9.13 \\
\hline Columba bollii & $8.93 \pm 19.26$ & 132 & 8.12 \\
\hline Erithacus rubecula & $8.49 \pm 12.46$ & 181 & 7.72 \\
\hline Cyanistes teneriffae & $8.29 \pm 14.39$ & 152 & 7.54 \\
\hline Serinus canarius & $2.34 \pm 9.01$ & 38 & 2.13 \\
\hline Sylvia atricapilla & $0.44 \pm 2.93$ & 11 & 0.40 \\
\hline Streptopelia turtur & $0.28 \pm 2.66$ & 6 & 0.25 \\
\hline Chloris chloris* & $0.16 \pm 2.18$ & 3 & 0.14 \\
\hline Carduelis carduelis* & $0.12 \pm 1.54$ & 3 & 0.11 \\
\hline Sylvia melanocephala & $0.08 \pm 1.259$ & 2 & 0.07 \\
\hline
\end{tabular}

Chloris chloris, Carduelis carduelis and Sylvia melanocephala represented only $0.32 \%$ of the assemblage, and were present at only few local spots of secondary growth or bushy marginal patches. Chloris and Carduelis were detected only at the road edge nearby the suburban forest limit at transect \#1 (table 3).

\section{COMMUNITY AND SPECIES LEVEL RESPONSES TO ROAD PROXIMITY AND ROAD ACTIVITY}

Structure and composition of the laurisilva bird community were not significantly different between road edges and forest interior (fig. 3, table 4). There were slightly higher richness, diversity, equitativity, overall population density and single species densities near road margins. General bird abundances were slightly higher along road edges, except for both Columba species. Two passerines (Fringilla and Phylloscopus) were significantly more abundant along road edges than at forest interior, whereas the endemic pigeon Columba was significantly more abundant at forest interior (table 5).

Traffic density varied between 175 and 3199 vehicles/day between the eastern (most remote) and the western suburban ends of the gradient (fig. 4). Noise levels were neatly higher along road edges $[\mathrm{Leq}=43.3 \pm 7.9 \mathrm{~dB}(\mathrm{~A})$; maximum $=96.2$ $\mathrm{dB}(\mathrm{A})]$ than at forest interior $[\mathrm{Leq}=36.7 \pm 4.8 \mathrm{~dB}(\mathrm{~A})$; maximum $=69.7 \mathrm{~dB}(\mathrm{~A})$ ] $(\mathrm{U}=13.049, \mathrm{p}<0.001)$ (fig. 5). 

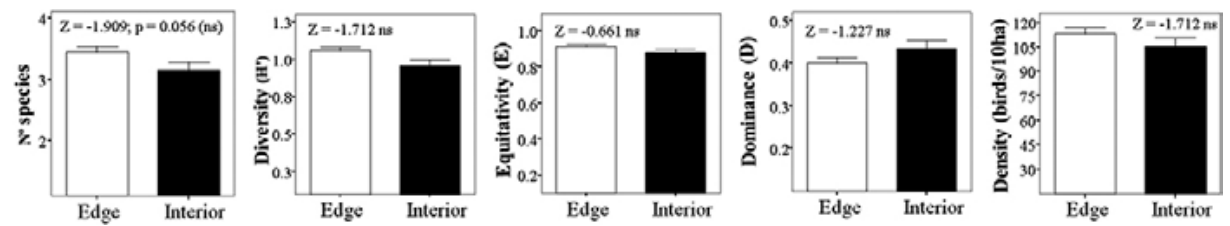

Figure 3. Comparison of parameters of bird community structure between road edge and forest interior (mean + 1SE) and Mann-Whitney's tests; ns = not significant.

\begin{tabular}{|c|c|c|c|c|c|c|}
\hline Transect & НавітAт & $\begin{array}{c}\text { S, } \\
\text { SPECIES } \\
\text { NUMBER }\end{array}$ & $\begin{array}{c}\text { SHANNON'S } \\
\text { H' }^{\prime}\end{array}$ & $\begin{array}{c}\text { SHANNON'S } \\
\text { E }\end{array}$ & $\begin{array}{c}\text { Simpson's } \\
\text { D }\end{array}$ & $\begin{array}{c}\text { DENSITY } \\
\text { (BIRDS/10 HA) }\end{array}$ \\
\hline 1 & Road edge & $4 \pm 2$ & $1.25 \pm 0.5$ & $0.41 \pm 0.02$ & $0.33 \pm 0.18$ & $134 \pm 72$ \\
\hline $2 \mathrm{~A}$ & Road edge & $4 \pm 2$ & $1.10 \pm 0.4$ & $0.40 \pm 0.02$ & $0.38 \pm 0.14$ & $134 \pm 65$ \\
\hline $2 \mathrm{~B}$ & Road edge & $3 \pm 1$ & $1 \pm 0.32$ & $0.42 \pm 0.02$ & $0.40 \pm 0.11$ & $104 \pm 45$ \\
\hline 3 & Interior & $5 \pm 1$ & $1.43 \pm 0.32$ & $0.41 \pm 0.01$ & $0.27 \pm 0.09$ & $173 \pm 71$ \\
\hline 4 & Road edge & $3 \pm 2$ & $0.95 \pm 0.54$ & $0.40 \pm 0.03$ & $0.46 \pm 0.25$ & $112 \pm 78$ \\
\hline 5 & Interior & $2 \pm 2$ & $0.63 \pm 0.54$ & $0.41 \pm 0.03$ & $0.55 \pm 0.27$ & $69 \pm 60$ \\
\hline 6 & Road edge & $3 \pm 1$ & $1.03 \pm 0.47$ & $0.41 \pm 0.02$ & $0.41 \pm 0.21$ & $107 \pm 57$ \\
\hline 7 & Interior & $3 \pm 2$ & $0.88 \pm 0.49$ & $0.42 \pm 0.02$ & $0.46 \pm 0.22$ & $93 \pm 67$ \\
\hline $8 \mathrm{~A}$ & Road edge & $4 \pm 2$ & $1.15 \pm 0.47$ & $0.41 \pm 0.02$ & $0.35 \pm 0.17$ & $110 \pm 53$ \\
\hline $8 B$ & Road edge & $4 \pm 1$ & $1.32 \pm 0.41$ & $0.41 \pm 0.02$ & $0.31 \pm 0.17$ & $143 \pm 65$ \\
\hline 9 & Interior & $3 \pm 2$ & $0.93 \pm 0.52$ & $0.40 \pm 0.04$ & $0.47 \pm 0.25$ & $105 \pm 57$ \\
\hline 10 & Road edge & $2 \pm 2$ & $0.72 \pm 0.59$ & $0.42 \pm 0.01$ & $0.53 \pm 0.29$ & $70 \pm 57$ \\
\hline 11 & Interior & $3 \pm 1$ & $1.02 \pm 0.52$ & $0.43 \pm 0.01$ & $0.38 \pm 0.21$ & $72 \pm 45$ \\
\hline \multicolumn{2}{|l|}{ Total } & $3 \pm 2$ & $1.02 \pm 0.53$ & $0.41 \pm 0.02$ & $0.41 \pm 0.23$ & $110 \pm 69$ \\
\hline
\end{tabular}

Minimum and maximum noise levels were significantly higher along roads than at forest interior (Minimum levels: $\mathrm{U}=5.079, \mathrm{p}<0.001$; maximum levels: $\mathrm{U}=13.406, \mathrm{p}<0.001)$. This was largely determined by peak noise recordings along roads (fig. 5). Apart from higher "baseline" noise levels, traffic noise generated a more variable and unpredictable sound environment near road edges than at forest interior (fig. 5).

We did not detect a significant association between maximum noise level (as a proxy for maximum negative impact on birds) and bird density or richness along road edges (table 6). Only 3 species showed a significant negative association 


\begin{tabular}{|c|c|c|c|}
\hline \multicolumn{4}{|c|}{$\begin{array}{c}\text { TABLE 5. DIFFERENCES (MANN-WHITNEY'S) IN MEAN DENSITY BETWEEN ROAD EDGE } \\
\text { AND INTERIOR FOREST FOR THE MOST FREQUENT BIRD SPECIES IN LAURISILVA. } \\
\text { THE NUMBER (N) OF 0.5 HA CENSUS SUBUNITS (3 REPLICATES INCLUDED) } \\
\text { IS SHOWN; NS = NOT SIGNIFICANT }\end{array}$} \\
\hline Species & ROAD EDGE $(\mathrm{N}=339)$ & INTERIOR $(\mathrm{N}=216)$ & $\mathrm{U}$ \\
\hline Regulus regulus & $1.54 \pm 1.2$ & $1.42 \pm 1.2$ & $1.29 \mathrm{~ns}$ \\
\hline Phylloscopus canariensis & $1.5 \pm 1.0$ & $1.28 \pm 1.2$ & $2.44^{*}$ \\
\hline Turdus merula & $0.65 \pm 0.9$ & $0.58 \pm 0.8$ & $0.89 \mathrm{~ns}$ \\
\hline Fringilla coelebs & $0.59 \pm 1$ & $0.35 \pm 0.6$ & $2.50^{*}$ \\
\hline Erithacus rubecula & $0.44 \pm 0.6$ & $0.40 \pm 0.7$ & $1.25 \mathrm{~ns}$ \\
\hline Cyanistes teneriffae & $0.42 \pm 0.7$ & $0.41 \pm 0.7$ & $0.49 \mathrm{~ns}$ \\
\hline Columba bollii & $0.3 \pm 0.8$ & $0.7 \pm 1.2$ & $4.90^{* *}$ \\
\hline Serinus canarius & $0.14 \pm 0.5$ & $0.07 \pm 0.3$ & $1.45 \mathrm{~ns}$ \\
\hline Streptopelia turtur & $0.02 \pm 0.2$ & - & $1.88 \mathrm{~ns}$ \\
\hline
\end{tabular}

${ }^{*} \mathrm{p}<0.05 ;{ }^{* *} \mathrm{p}<0.001$

A

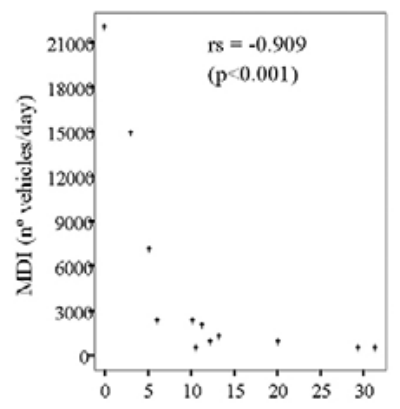

B

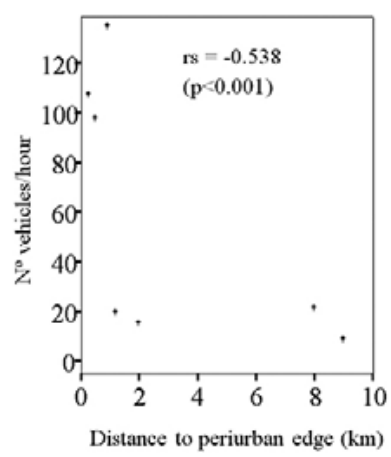

C

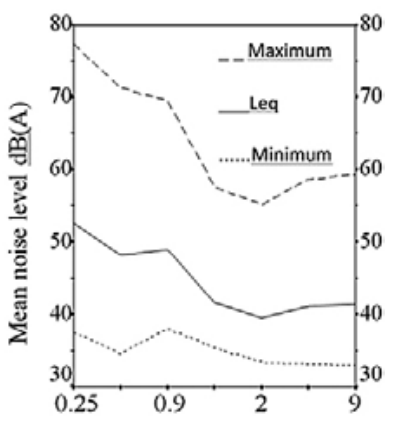

Figure 4. Effect of distance of bird road transects to the periurban zone on traffic density and noise level. A, MDI: Mean Daily Intensity (vehicles/day) (Cabildo de Tenerife 2001). Distance measured as kilometers of "driving" distance on the road, to obtain a measure of accessibility to cars and humans; B, hourly traffic intensity; C, noise level recorded during bird censuses (distance measured in straight line on a map).

Shown are Spearman correlations and $\mathrm{p}$ values.

with maximum noise levels (table 6). Population density of Columba was negatively associated with noise level. On the other hand, densities of Serinus and Cyanistes showed weak positive associations with noise levels. Vehicle traffic density, measured both as $n .{ }^{\circ}$ vehicles/h (from our transects) and official MDI data (Cabildo de Tenerife, 2001) was significantly higher near the suburban area and followed a decreasing gradient toward the eastern end of Anaga (table 1, fig. 4). 

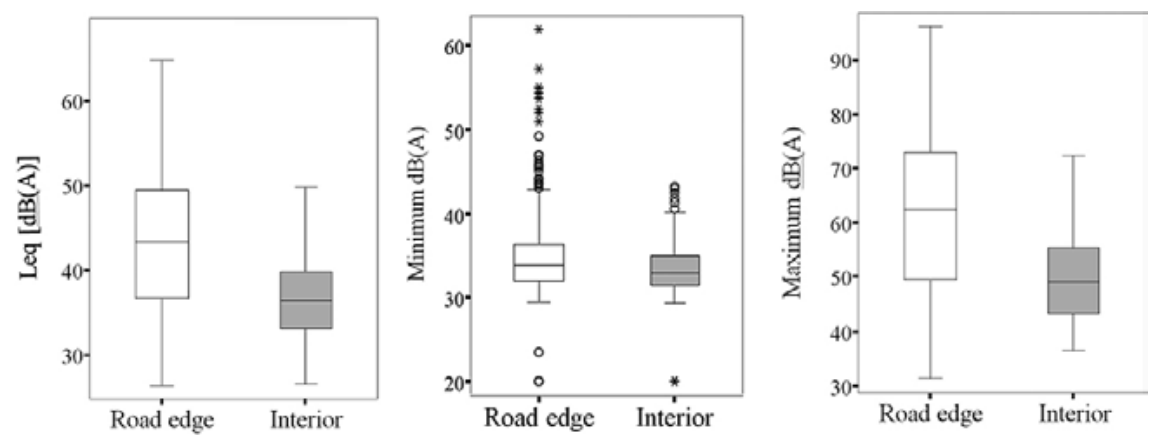

Figure 5. Variation in levels of traffic noise between road edge and laurel forest interior. Diagrams show median (horizontal line), quartiles, standard error, extreme values (o) and atypical values $(*)$.

TABLE 6. SPEARMAN $\left(\mathrm{R}_{\varsigma}\right)$ AND PARTIAL CORRELATIONS (CP, EDGE VS INTERIOR) BETWEEN THE MAXIMUM NOISE LEVEL [DB(A)], TRAFFIC DENSITY (N. ${ }^{\circ}$ VEHICLES/H), DISTANCE TO THE MAIN URBAN AREA (KM) AND DENSITY OF THE MOST FREQUENT LAUREL FOREST BIRD SPECIES. NOISE-ABUNDANCE CORRELATIONS WERE ONLY CALCULATED FOR BIRDS ALONG FOREST ROAD EDGES

\begin{tabular}{|c|c|c|c|c|}
\hline Species & $\frac{r_{s}}{\text { (VEHICLES/H) }}$ & $\begin{array}{c}\mathrm{r}_{\mathrm{s}} \\
\text { DISTANCE TO } \\
\text { URBAN AREA }(\mathrm{KM})\end{array}$ & $\begin{array}{c}\mathrm{Cp} \\
\text { DisTANCE TO } \\
\text { URBAN AREA (KM) }\end{array}$ & $\stackrel{r_{s}^{s}}{D B(A)}$ \\
\hline Regulus regulus & $-0.025 \mathrm{~ns}$ & $0.372^{*}$ & $0.342 \mathrm{~ns}^{2}$ & $0.037 \mathrm{~ns}$ \\
\hline Phylloscopus canariensis & $0.078 \mathrm{~ns}$ & $0.018 \mathrm{~ns}$ & $-0.222 \mathrm{~ns}$ & $0.105 \mathrm{~ns}$ \\
\hline Turdus merula & $-0.034 \mathrm{~ns}$ & $0.039 \mathrm{~ns}$ & $-0.150 \mathrm{~ns}$ & $0.148 \mathrm{~ns}$ \\
\hline Fringilla coelebs & $0.209 \mathrm{~ns}$ & $0.023 \mathrm{~ns}$ & $-0.075 \mathrm{~ns}$ & $0.086 \mathrm{~ns}$ \\
\hline Erithacus rubecula & $-0.115 \mathrm{~ns}$ & $0.310 \mathrm{~ns}$ & $-0.114 \mathrm{~ns}$ & $-0.139 \mathrm{~ns}$ \\
\hline Cyanistes teneriffae & $0.038 \mathrm{~ns}$ & $-0.020 \mathrm{~ns}$ & $-0.132 \mathrm{~ns}$ & $0.294^{* *}$ \\
\hline Columba bollii & $-0.730^{* * *}$ & $0.604^{* * *}$ & $0.326 \mathrm{~ns}^{1}$ & $-0.278^{* *}$ \\
\hline Serinus canarius & $0.137 \mathrm{~ns}$ & $-0.294 \mathrm{~ns}$ & $-0.306 \mathrm{~ns}$ & $0.272^{* *}$ \\
\hline $\begin{array}{l}\text { Overall population density } \\
\text { (birds/10 ha) }\end{array}$ & $0.156 \mathrm{~ns}$ & $-0.280 \mathrm{~ns}$ & $-0.382^{*}$ & $0.062 \mathrm{~ns}$ \\
\hline Richness ( $n^{\circ}$ of species) & $0.065 \mathrm{~ns}$ & $-0.238 \mathrm{~ns}$ & $-0.433^{*}$ & $0.102 \mathrm{~ns}$ \\
\hline Shannon's diversity (H') & $0.168 \mathrm{~ns}$ & $-0.269 \mathrm{~ns}$ & $-0.470^{* *}$ & $0.023 \mathrm{~ns}$ \\
\hline Shannon's equitativity (E) & $0.194 \mathrm{~ns}$ & $-0.384^{*}$ & $-0.552^{* * *}$ & $-0.036 \mathrm{~ns}$ \\
\hline Simpson's dominance (D) & $-0.152 \mathrm{~ns}$ & $0.302 \mathrm{~ns}$ & $0.478^{* *}$ & $-0.042 \mathrm{~ns}$ \\
\hline
\end{tabular}

${ }^{*} \mathrm{p}<0.05 ;{ }^{* *} \mathrm{p}<0.01 ;{ }^{* * *} \mathrm{p}<0.001 ;$ ns: not significant; ${ }^{1} \mathrm{p}=0.06 ;{ }^{2} \mathrm{p}=0.05$.

The noise level showed a significant but weak negative correlation with distance to the suburban area (maximum $\mathrm{dB}(\mathrm{A}): \mathrm{r}_{\mathrm{s}}=-0.240, \mathrm{p}<0.001$; minimum 

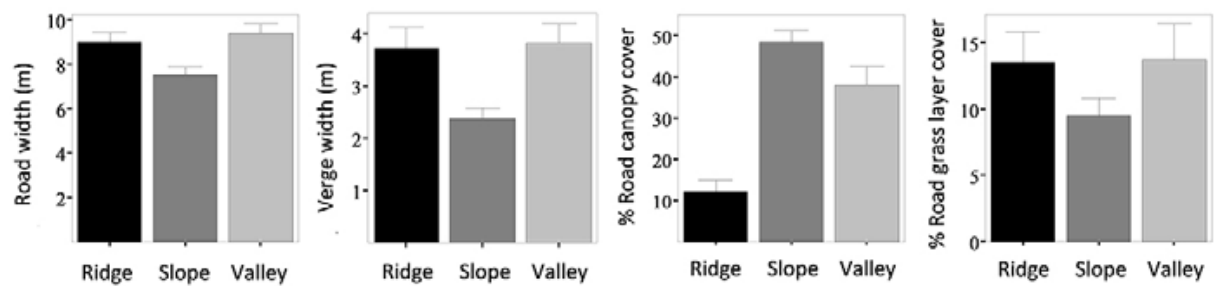

Figure 6. Variation in road width (total and road edges only) and vegetation cover along a topographic gradient in laurisilva.
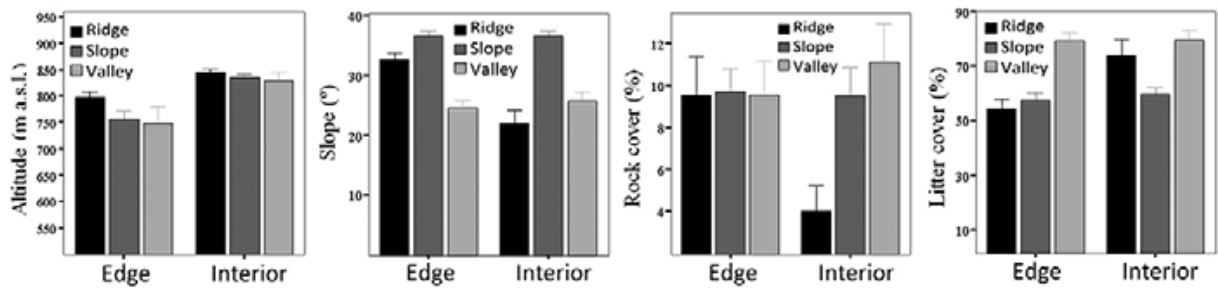

Figure 7. Comparison of variation in altitudinal location, slope and substrate features along a topographic gradient in laurisilva roads and interior areas.

$\mathrm{dB}(\mathrm{A}):-0.170, \mathrm{p}<0.001$; Leq: $-0.222, \mathrm{p}<0.001)$. Between gradient extremes, the difference in maximum sound pressure was $17 \mathrm{~dB}(\mathrm{~A})$, whereas basal sound pressure was only $4 \mathrm{~dB}(\mathrm{~A})$ and Leq increased in $11 \mathrm{~dB}(\mathrm{~A})$ between the suburban road and remote forest areas (fig. 4).

Population density of the pigeon Columba decreased near the suburban edge and showed a strong negative response to traffic density (table 6). Density of Regulus also decreased near the suburban edge, although it showed no significant response to noise levels (table 6). On the other hand, densities of Cyanistes and Serinus were positively correlated with noise levels (table 6). Densities of the remaining species were not significantly related with traffic density or noise levels (table 6).

After controlling for situation (road edge vs. interior) by partial correlation, population density of all species combined increased significantly near the suburban edge. Finally, community richness, diversity and equitativity showed a significant increase toward the suburban edge (table 6).

\section{HABITAT HETEROGENEITY, TOPOGRAPHY AND ROAD PROXIMITY}

The studied sites encompassed a relatively narrow altitudinal range ( $-100 \mathrm{~m})$ within the Anaga laurisilva, and we considered that the altitude effect on bird community composition was negligible at the ecosystem scale (fig. 6). Mean slope was similar for hillsides and valleys in both edge and interior (fig. 7). Roads and 


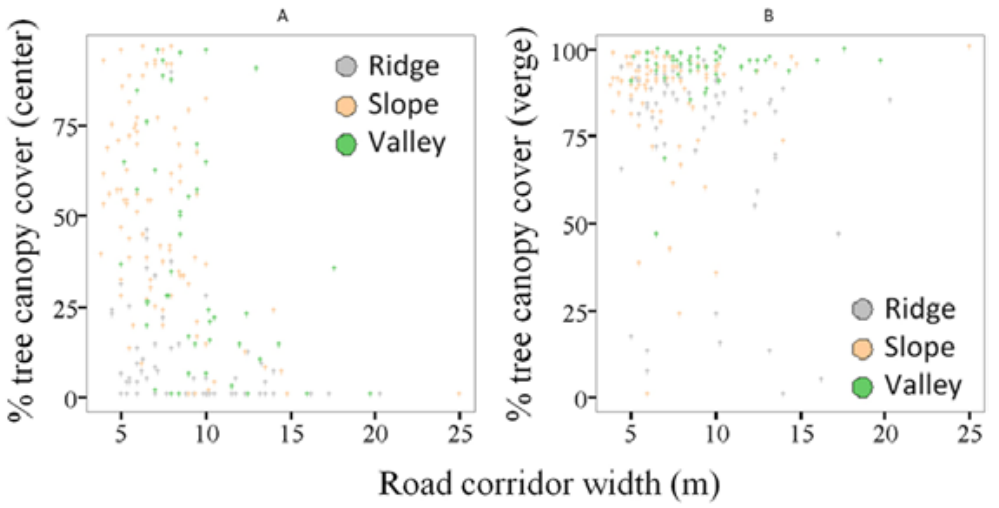

Figure 8. Effect of road width (asphalt lanes + open verges) on canopy cover [at the center of the road (A) and at $5 \mathrm{~m}$ from edge (B)] controlling for topography. Partial correlations: (A) $r=-0.456, p<0.001$; (B) $r=-0.095, p=0.183$.

road edges were wider in valleys and ridges, and narrower in hillsides (fig. 6, overall mean road width: $8.4 \pm 3.3 \mathrm{~m}$ ).

Grass cover within the road corridor was directly correlated with verge width. Ridges and valleys showed a denser grass layer than slopes (fig. 6). Rock cover increased significantly from ridges to hillsides to valleys, but only at forest interior (fig. 7). Litter cover was lower along ridge road edges than in other situations, but it did not differ between slopes and valleys nor between edge and interior (fig. 7). Tree cover over the road was denser on slopes $(-45-50 \%)$ and valleys $(-40 \%)$ than on ridges $(-10 \%)$ (fig. 6$)$. Tree canopy cover over the road center, and road width, were negatively correlated (fig. 8).

With only a few exceptions, the structure and floristic composition followed similar patterns of variation with topography when comparing edge and interior (fig. 9). Canopy height, cover, tree species richness, number of fleshy-fruited plant species, number of vertical vegetation strata, and number of trees with $\mathrm{DBH}>10$ $\mathrm{cm}$ increased from ridge to slope to valley, regardless of road proximity (fig. 9). Conversely, shrub cover and richness, stump density, and number of trees with $\mathrm{DBH} £ 10 \mathrm{~cm}$ decreased from ridge to slope to valley, and mostly regardless of road vicinity. Ridge habitats were an exception because shrub richness and cover, grass cover and density of trees with $\mathrm{DBH}<10 \mathrm{~cm}$ were higher at forest interior than along road edges. Stump density (an indicator of intensity of selective wood extraction) was always larger near road edges than at forest interior.

A great heterogeneity was observed in bird abundance regarding the topographic pattern in interaction with road proximity (fig. 10). Abundance of 6 of the 8 most frequent species did not vary among topographic categories. Columba was more abundant in valley bottoms than on slopes or ridges, and in forest interior than at the forest edge. Phylloscopus was more abundant on hillsides 

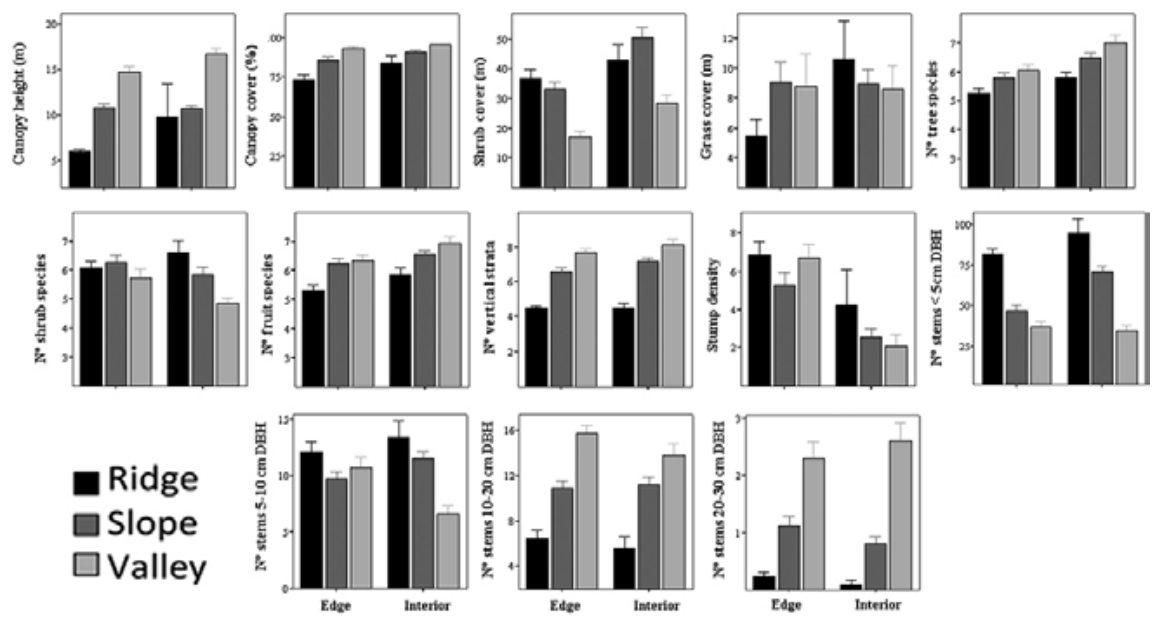

Figure 9. Variation in vegetation structure and floristic composition along the topographic gradient in laurisilva roads and interior areas.
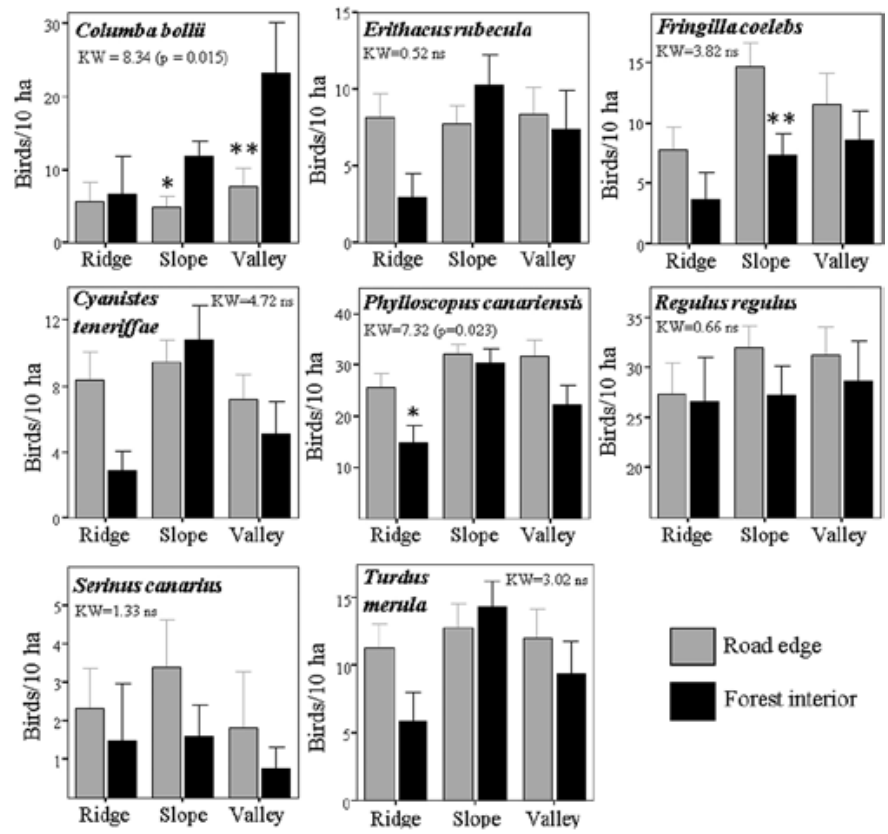

Figure 10. Variation in bird population density along the topographic gradient in laurisilva roads and interior. For each species: Kruskal-Wallis chi-square tests and $\mathrm{p}$ values are shown; ns $=$ not significant $(\mathrm{p}>0.05)$; significant differences between road edge and interior for each topographic category (Mann-Whitney's $\mathrm{U},{ }^{*} \mathrm{p}<0.05$; ${ }^{* *} \mathrm{p}<0.01$ ); the remaining edge-interior differences were not significant. 


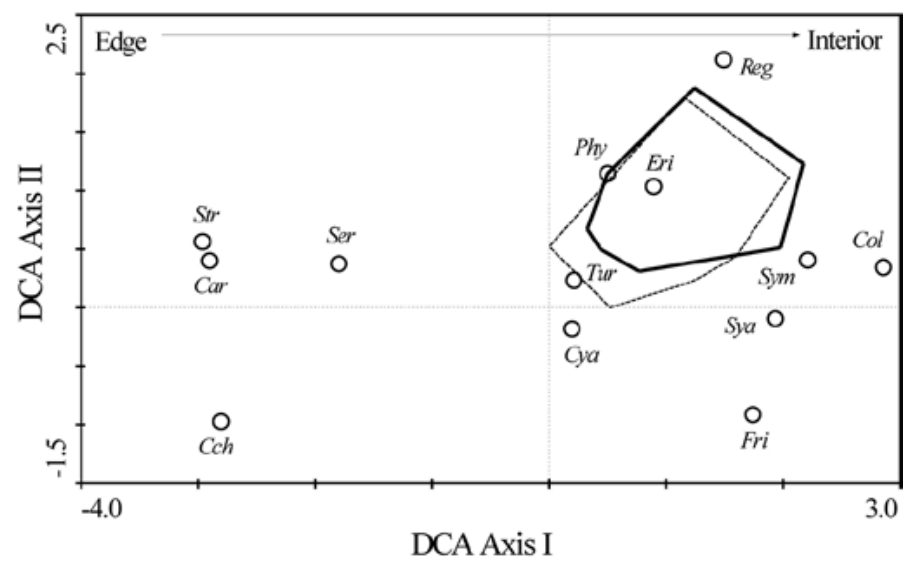

Figure 11. Detrended Correspondence Analysis (DCA) of the laurisilva bird community. Plot of species in the ordination space defined by the 2 first axes. Polygons comprise the sample space of road edges (dotted line) and interior (black line). Axis units are mean typical deviations (DT) of species turnover. Species codes as in fig. 2.

and valley bottoms tan along ridges, where it was more abundant along road edges. Fringilla was more abundant at the edge and did not exhibit variation regarding topography. The remaining species presented higher population densities along road edges excepting Erithacus, Cyanistes and Turdus, which were more abundant at the interior of hillside forests.

\section{VEGETATION GRADIENTS AND MULTIVARIATE ASSOCIATIONS}

Forest edge and interior showed a high degree of overlapping in terms of bird species composition and abundance (fig. 11). The two first DCA axis described $40 \%$ of variance in the distribution of bird species, with the first axis indicating the most intense gradient (Axis I: $-26 \%$, Axis II: $\sim 14 \%$; table 7, fig. 11). The small spatial segregation of samples between edge and interior is explained by the scarce separation of dominant species along the first axis (compare abundances in tables 3 and 5). Habitat generalists like Phylloscopus, Cyanistes, Erithacus, and Turdus had an intermediate position along the gradient. The first ordination axis sorted the edgerelated species (Chloris, Carduelis, Serinus and Streptopelia). Both Sylvia species scored high mainly in marginal habitats. Columba exhibited a higher dependence of forest patches far from roads, as suggested by its high scoring on the first axis.

Direct gradient analysis (CCA) accounted for a significant contrast in habitat features between edge and interior. First and second axis explained 41.3 and $17 \%$ of the variance in the relationship birds-habitat (table 7, fig. 12). Axis I showed significant positive correlations with canopy tree species richness, canopy cover 


\begin{tabular}{|c|c|c|}
\hline DCA (sPECIES) & Axis I & Axis II \\
\hline Eigenvalues & 0.182 & 0.1 \\
\hline$\%$ cumulative variance & 25.8 & 40 \\
\hline Gradient length & 2.173 & 1.875 \\
\hline \multicolumn{3}{|c|}{ CCA (SPECIES-HABITAT RELATIONSHIPS) } \\
\hline Eigenvalues & 0.029 & 0.012 \\
\hline$\%$ cumulative variance & 41.3 & 58.3 \\
\hline Species-habitat correlations & 0.490 & 0.391 \\
\hline \multicolumn{3}{|c|}{ Habitat variables-axis correlations } \\
\hline TreeSpp & -0.639 & \\
\hline CCover & -0.629 & \\
\hline CHeight & -0.465 & \\
\hline T20 & -0.416 & \\
\hline GrassCov & 0.405 & \\
\hline $\mathrm{T} 10$ & -0.366 & \\
\hline ShrubCov & 0.340 & \\
\hline Slope & 0.328 & \\
\hline $\mathrm{T} 30$ & -0.163 & \\
\hline ShrubHe & & -0.593 \\
\hline $\mathrm{T} 5$ & & 0.540 \\
\hline Stump & & 0.361 \\
\hline NStra & & -0.344 \\
\hline
\end{tabular}

$\left(\mathrm{R}^{2}>0.6\right)$, height, density of stems $\leq 20 \mathrm{~cm} \mathrm{DBH}$ and grass cover $\left(\mathrm{R}^{2}>0.4\right)$ (table 7$)$. The density of stems $\leq 10 \mathrm{~cm}$ and $>30 \mathrm{~cm} \mathrm{DBH}$, average terrain slope and shrub cover had a weak significant influence (axis I) on bird abundance $\left(R^{2}<0.4\right)$ (fig. 12). Axis II had higher scores in variables describing marginal forest conditions (taller shrub patches, higher density of stems $<5 \mathrm{~cm} \mathrm{DBH}\left[\mathrm{R}^{2}>0.5\right]$, diversity of vegetation layers and higher disturbance due to selective wood extraction of mainly stems $<5 \mathrm{~cm}$ $\mathrm{DBH}\left[\mathrm{R}^{2}-0.3-0.4\right)$. These factors were related to more dense vegetation next to road edges, where bird density was slightly higher, contrasting with interior mature stages largely preserved from human disturbance. 


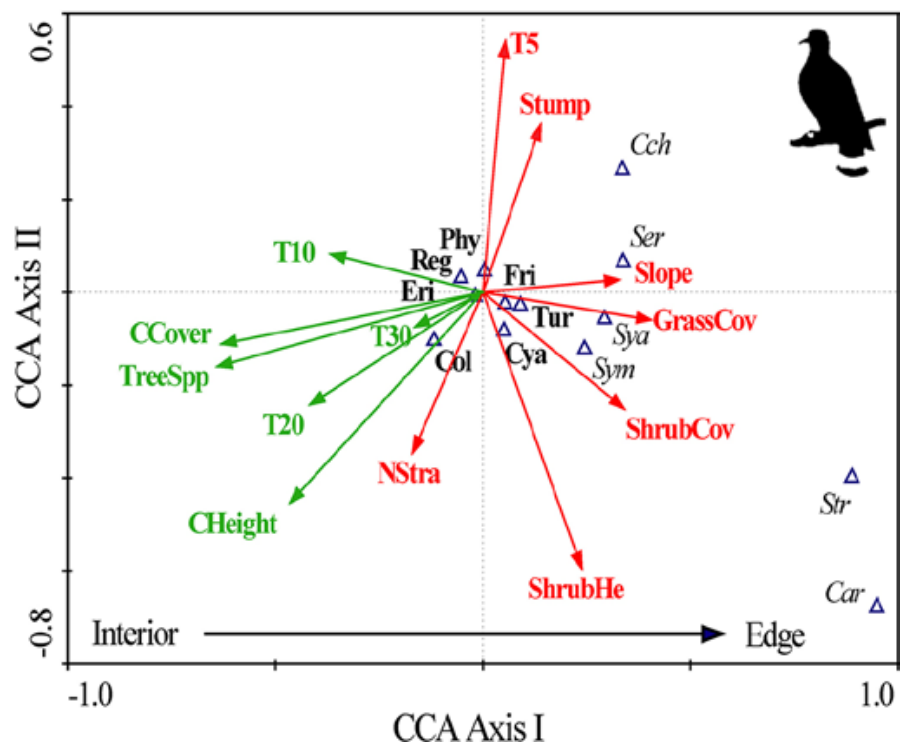

Figure 12. Canonical Correspondence Analysis (CCA) of the bird-habitat relationships. Biplot of species/variables in the ordination space defined by the first 2 axis (table 7).

Arrows: direction of the most intense environmental change in the focal variable; its length is directly related to the importance in community structuring; its direction shows its degree of association to the respective axis; angles between arrows indicate correlation between variables (the smaller angle, the stronger correlation); the position of species regarding variables suggests habitat preferences. Species and variable codes as in fig. 2 and table 2. The following variables were excluded to avoid redundancy based on a previous PCA: RockCov, LittCov, Tm30, FruitSpp, ShrubSpp. The positive section of Axis I scored high in variables related to marginal habitats and secondary forest (red), which were in general more densely vegetated. The negative section of Axis I scored high in variables indicating more mature forest (green). Note the aggregation of dominant bird species (bold) near the axes coordinate origin. The variables showing a stronger correlation with Axis I were CHeight, TreeSpp, CCover and T20 whereas ShrubHe, T5, Stump and NStra were related more strongly with Axis II (table 7).

\section{MODALITY OF BIRD RESPONSES TO ROAD PROXIMITY AND HABITAT CONFIGURATION}

The responses (Lowess regression curves) of species density to habitat gradients were very heterogeneous (fig. 13). Erithacus and Regulus exhibited clear unimodal responses along both axes. Phylloscopus displayed higher densities at intermediate conditions between edge and interior (fig. 12). Columba, Fringilla, Cyanistes, Serinus, Streptopelia and Turdus revealed lineal associations with different gradients. Columba responded negatively $\left(\mathrm{R}^{2}-0.3\right)$ to forest disturbance depicted by increases of Axis I (fig. 12). The remaining 5 species exhibited the opposite trend, positive responses to increases in the disturbance gradient (Axis I). Fringilla was 

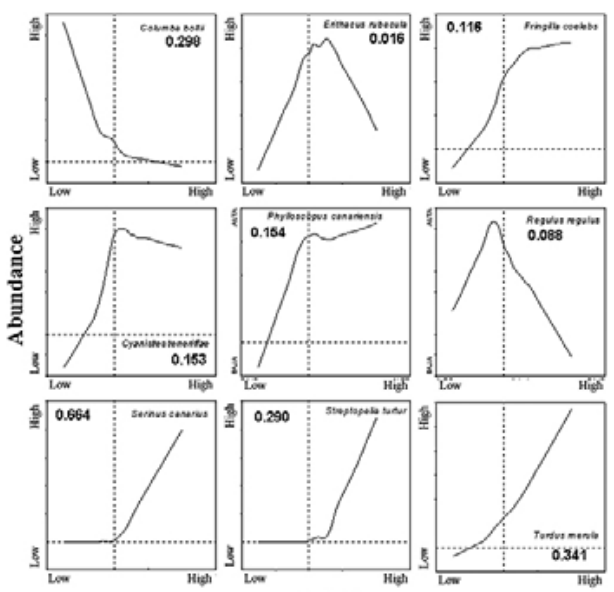

Axis I
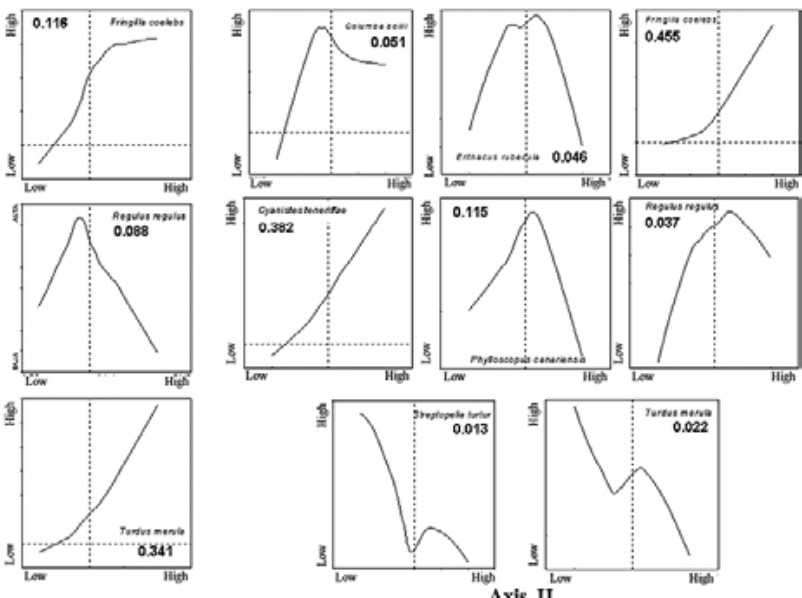

Axis II

Figure 13. Species-habitat relationships. Locally-weighted regression functions (Lowess) on bird abundances along the environmental gradient defined by the CCA (table 7, fig. 11). Shown are $\mathrm{R}^{2}$ values for each function. The $\mathrm{R}^{2}$ for Serinus canarius on Axis II was 0 (no adjustment obtained).

associated to greater vegetation density and disturbance degree occurring along road margins (Axis II). Cyanistes showed a lineal monotonic increase in abundance toward road edges. Both Cyanistes and Fringilla exhibited more intense responses to changes in forest structure with independence of road proximity (Axis II). However, Serinus, Turdus, and Streptopelia showed higher positive influence of road proximity (larger variance explained by Axis I).

\section{DISCUSSION}

\section{RESPONSES OF THE LAURISILVA BIRD COMMUNITY TO ROAD PROXIMITY}

Our results revealed that: 1 ) the general structure of the laurisilva breeding bird community changed relatively little in the vicinity of narrow forest roads; 2 ) regarding population density, $91 \%$ of the assemblage is formed by Passeriformes (only 2 insectivores equaled $50 \%$ of the overall density); with such a distinctively high dominance, it seems not surprising that the community profiles, species composition and abundance of different guilds were very similar between interior and road edges; any contrast could be ameliorated by generalized high densities of all principal species (especially of Phylloscopus); 3) although most species showed wide tolerance to road proximity, the palaeoendemic Columba bollii was characterized as the most interior-preferring species of the assemblage. Abundance of this pigeon decreased neatly near roads. Responses to road proximity of the two dominant passerines were 
weakly positive (Regulus) or even moderately positive (Phylloscopus); this was also the situation for the rest of mostly habitat-generalist species (including passerines and Streptopelia); 4) moderate increase of bird population density along road edges remained consistent after controlling for the effects of traffic, noise, habitat structure and foraging behavior.

We found similar abundance and diversity indicators between road edges and interior in a previous study in Tenerife forests (Delgado et al. 2008). In coherence with this finding, most bird species showed only slight differences in abundance between road edges and forest interior. Only Turdus was more abundant along unpaved tracks than at forest interior or asphalt roads, whereas four birds (Columba, Fringilla, Regulus and Serinus) were more abundant at forest interior (Delgado et al. 2008).

Our results are consistent with the traditional hypothesis of increase of density and richness of bird populations at ecotonal zones (Odum 1971, De Graaf 1992). However, this occurs at the cost of reduced presence of species sensible to road edges, whilst gaining generalist elements near road margins. At a landscape scale, this would involve an overall reduction in richness, diversity, and singularity for the island laurisilva. Blair (1996) also found that the more sensitive native species were less frequent and abundant towards areas with a higher road proliferation and human use. However, richness, diversity and global bird biomass increased at the intermediate disturbance levels. The Anaga laurisilva would exemplify a similar situation, even when sensitive species (Columba bollii) responded negatively.

The laurisilva bird community could be divided into three classes regarding road tolerance. A first group is formed by a single, interior-preferring species (Bolle's pigeon). Apart from their status as palaeoendemics, these pigeons have several functional traits which distinguish them from the other bird species (Appendix 1). Columba bollii has a long incubation period, and a small clutch size (1 egg) involving higher risk of predation (Hernández et al. 1999, Martín and Lorenzo 2001). Rats are the chief nest predators of both Columba species in laurisilva (Hernández et al. 1999, Delgado et al. 2005). Road synergies with alien predators such as rats may induce losses in vulnerable birds. Rats are widespread in the laurisilva of Tenerife, occupying all vegetation layers (Contreras 1988, Hernández et al. 1999). In the Anaga laurel forest, rats exerted higher predation pressure along road edges than at forest interior, and along road margins on ridges and slopes than at ravine beds (Delgado et al. 2001). Breeding success in Bolle's pigeon has been found correlated with low density of bush understory, distance of nest to trunk and distance to inferior canopy (Hernández et al. 1999). Sparse understory and larger and taller trees are typical features of the interior patches of laurisilva. These findings are all consistent with our result of a higher abundance and activity of Bolle's pigeons at forest interior than near roads. At least for this forest-dependent species, large forest areas would ensure mature forest structure, high-quality nesting sites, food, and adequate distance from road disturbance.

The group of edge-preferring taxa (formed by Sylvia melanocephala and S. atricapilla, Carduelis, Chloris, Serinus, and Streptopelia) was more frequently found near road edges. Finally, a group of road-tolerant birds (Cyanistes, Erithacus, Phylloscopus, Regulus, Fringilla) can be defined, species with variable responses to 
road vicinity. In this group, Regulus is the most forest-dependent and road-avoiding element, and Phylloscopus the most road-tolerant (coherently, it is also the most widely distributed passerine in the Canary Islands; Martín and Lorenzo 2001).

\section{ROAD EDGE EFFECTS ON FOREST BIRDS FROM A BIOGEOGRAPHICAL PERSPECTIVE}

Research on bird community responses to road edges has reported both absence and existence of edge effects in temperate forests. Large expanses of territory have been transformed into homogeneous agricultural land, where contrasting roadside vegetation is associated to high bird density and diversity (Forman $e t$ al. 2002a). Kroodsma (1984) found similar densities along edges and interior of North American forests. Small and Hunter (1989) did not find changes in abundance and composition at forest-corridor ecotones. Hunter et al. (2001) found that birds of early successional stages or disturbance-dependent birds benefited from road edge use. Higher bird population densities have been described from abrupt edges in North America and Europe (DeGraaf 1992). Other works, however, have associated road proximity with negative effects on native and migrant birds (Ferris 1979, Rich et al. 1994). In agricultural land in Australia, most passeriformes responded negatively to disturbed road margins, because they offered low quality nesting and foraging sites and of refuge against predators (Lynch and Saunders 1991). Roads may favor generalist species depending on the type of traversed habitat (Meunier et al. 1999). Blair (1996) found that richness, diversity and global bird biomass increased at intermediate disturbance levels along a gradient of road density and human use. Persistence of bird populations of the forest-dependent species can be negatively affected by roads, as in Iberian pine fragments surrounded by agricultural matrix (Brotons and Herrando 2001).

As far as human-generated edges are concerned, a latitudinal gradient in sensitivity of the avifauna seem to occur. Tropical forests usually suffer net losses of density and diversity near edges (Bierregaard 1990, Báldi 1996, Canaday 1997, Watson et al. 2004), whereas temperate forests frequently experience general increases (Wilcove et al. 1986, Santos and Tellería 1998). Some induced forest edges, however, experience increases in open-canopy or edge species whilst interior species avoid these zones (Whitcomb et al. 1981, McWethy et al. 2009). In tropical forests overall biodiversity and climatic homogeneity over large spatial scales are comparatively higher than in temperate zones, and this would be related to differential sensitivity of birds to proliferation of artificial edges (Dale et al. 1994). On the contrary, in temperate ecosystems human influence is secular, both natural and artificial fragmentation is intense and the landscape heterogeneous (Harris 1984, Báldi 1996), features that would increase presence of species of wider ecological amplitude. The laurisilva bird community shows mostly features typical of a temperate-zone assemblage. Many bird species shared by the Canaries and the Palearctic have similarly weak density responses or even edge-proneness (Carrascal et al. 1992, Moskát and Waliczky 1992, Meunier et al. 1999, Brotons and Herrando 2001, Carrascal and Palomino 2005, Morelli et al. 2014). 
Several factors may be postulated to explain the moderate to low road edge effect appreciated in this bird community. Firstly, insularity is related with fewer species, increases in average density per species (which compensates for absence of competing taxa), interannual stability in species composition, species richness and niche expansion (Báez 1992, Oliveira et al. 1998, Whittaker \& Fernández-Palacios 2007); species impoverishment and niche expansion have also been suggested in other studies (Carrascal et al. 1992). These processes could provide adaptive advantages to many bird species in the fragmented laurisilva. Secondly, higher availability of marginal habitats coinciding with high prevalence of species related to such environments (Brotons and Herrando 2001).

From the review by Báldi (1996: p. 165) on anthropogenic edges in mainland temperate areas, $30-75 \%$ (mean: $-60 \%$ ) of species was indifferent to edges, $34 \%$ was formed by edge species and only $10 \%$ were strictly interior species. The overall response of the avifauna of subtropical laurisilva is consistent with this geographical pattern. In our study, out of 13 species, $12(-92 \%)$ showed indifference or appetence for road edges. We neither found a strong contrast between vegetation structures used by birds along roads or interior (fig. 12). In sum, this result is consistent with a majority of species showing some affinity or/and ample limits of tolerance for narrow road edges (Delgado et al. 2008).

INTERACTION OF TRAFFIC AND OROGRAPHY: IMPLICATIONS FOR LAUREL FOREST BIRDS

Many factors are involved in appetence for or avoidance of roads by birds. Negative effects of roads on bird populations have been most frequently attributed to traffic noise and mortality (Forman et al. 2002a). This depends on the type of habitat, species vulnerability, requirements and tolerance to road disturbance, and on the magnitude, extension and chronicity of impacts derived from road use (Jaeger et al. 2005). Noise produced by busy roads has been correlated to large reductions in abundance of breeding bird populations (Reijnen and Thissen 1987, Reijnen et al. 1997, Forman et al. 2002b, Parris and Schneider 2008). Along with induced topographical complexity, road corridors on grassland introduce prominent and diverse vegetation elements attracting a variety of bird species, leading to local increment in species richness and abundance, especially along the quieter and narrower roads (Forman et al. 2002). It has been also suggested that birds tend to avoid infrastructures more consistently in open habitat than in forests (BenítezLópez et al. 2010).

Orographic complexity in the laurisilva is a shaping factor in vegetation pattern and the associated bird assemblages (Martín et al. 2000). Levels of traffic noise would be strongly modulated by relief and remoteness in highly convoluted mountain roads such as in our study area. Noise avoidance and aversion to the road right-ofway and passing cars by birds, may be ameliorated by screening of dense vegetation, steep slopes and convoluted road design adapting to relief (Wolf et al. 2013).

Among causes adduced to explain why birds avoid roadsides include sing distortion and stress (Reijnen and Foppen 1994, Reijnen et al. 1995, Parris and 
Schneider 2008). These pressures reduce habitat quality of breeding insectivorous passerines (eg, Phylloscopus trochilus, Reijnen and Foppen 1994). Reijnen et al. (1997) found that 33 of 45 forest species $(73.3 \%)$ decreased their population densities near highways. These authors found that Regulus and Fringilla were negatively affected by noise. In another study, however, Turdus and other birds did not experience reductions due to traffic noise (Reijnen and Thissen 1987). Brotons and Herrando (2001), in Pinus halepensis fragments found lower occurrence of forest species (both specialist and generalist birds) near highways, although the effects were weaker for secondary roads. In our case, most bird species (or their close relatives) shared with mainland areas, did not show significant negative responses to traffic noise.

Some roads have been suggested to offer suitable nesting sites in their vicinity that could be scarce in the adjacent habitats, and this factor could compensate reductions in habitat quality due to traffic (Morelli et al. 2014). Increases in species richness along highway edges with forest and cultured land have also been found even with traffic intensities of 25,000-52,000 cars/day (Meunier et al. 1999). Environmental factors such as roadside vegetation structure, quality of adjoining habitats, or topography would affect noise levels and other road-related disturbances acting on birds (Reijnen et al. 1997). For lower noise pressures, some authors have not observed negative effects on bird abundance. Under a 36-58 dB(A) threshold in forests, bird abundance was not affected, though it was reduced $35-100 \%$ when noise levels exceeded $58 \mathrm{~dB}(\mathrm{~A})$ depending on species (Reijnen et al. 1997). In our work, traffic intensity was lower (averaging -1229 vehicles/day) than those recorded in most studies (table 1). Sound levels were nevertheless relatively high on all the segments, and peak values were recorded even at the most remote forest stands along the road transect. Notably, noise levels were negatively correlated with abundance of the two most neatly forest-dependent species in these laurel forests (Regulus and Columba) although the negative response of the endemic pigeon was the most intense. These results add evidence of negative impact of traffic noise amplitude on passerines and other birds (Weiserbs and Jacob 2002, Peris and Pescador 2004).

The Bolle's pigeon may be considered a key frugivorous bird species in the laurel forest (Martín et al. 2000, Marrero et al. 2010). Its presence and abundance indicates the degree of conservation of the forest and of other taxa, largely due to its fruit consumer role. Roads in this study reach forest stands far from urban areas, facilitating human accessibility to critical areas for such sensible birds. At the same time, forest roads extend edge effects at local and regional scales, inducing additional disturbances of forest areas (road and trail construction, edifications, trampling, dumping, tourism, noise, illegal hunt, among other factors; Martín et al. 2000), as shown from other places (Heilman et al. 2002, Weiserbs and Jacob 2002, Riitters and Wickham 2003). This cumulative process is clearly harmful for vulnerable birds like Columba, which demand large (or at least quiet, undisturbed smaller forest patches) and exhibit forest dependence for mating, breeding and foraging (Canaday 1997; Martín et al. 2000). In contrast with most small to medium-sized forest birds, our results suggest, from several angles, detrimental impacts on the frugivorous pigeons next to the suburban edge in Anaga. Traffic intensity, noise level, suboptimal altered vegetation structure and composition (lower height, cover, 
tree diversity, and higher understory density from logging) are the main suggested factors of disturbance. Other potential road impacts which could create negative synergies with the above mentioned are the alteration of roadside microclimate, alteration of vegetation structure and composition, nest predation, and collision with vehicles. Relatively high traffic noise levels and road-related disturbances to populations of some forest-dependent species may be produced even by narrow roads in these island forests.

Some of the limitations of our study refer to palaeoendemic pigeons (focused on the more abundant Columba bollii in our study area). We have not included here the detailed use of foraging space or daily and seasonal activity patterns (mating and foraging activities), which include extensive movements of Bolle's pigeons (Martín et al. 2000, Martín and Lorenzo 2001). These columbiforms are regular users of the roadsides in their search for food and water, especially in the early or late afternoon when there is little or no traffic, and not unfrequently, they use road and trail edges for nesting. The use of habitat by pigeons can be significantly influenced by variation in human presence and motorized traffic, which increases on weekends in these forest areas due to tourism. Studies are needed on the use of the habitat and its spatio-temporal variation depending on the incidence of traffic and the human presence and accessibility to the protected pigeon habitats.

\section{ACKNOWLEDGEMENTS}

We thank Samuel González, Carlos G. Escudero, Gustavo Morales and Manuel Marrero for helping during field work or supplying material. 


\section{REFERENCES}

Arévalo, J.E. and Newhard, K. 2011. Traffic noise affects forest bird species in a protected tropical forest. Revista de Biología Tropical 59: 969-980.

BÁEZ, M. 1992. Zoogeography and evolution of the avifauna of the Canary Islands. Natural History Museum of Los Angeles County Science Series 36: 425-431.

BÁLDI, A. 1996. Edge effects in tropical versus temperate forest bird communities: three alternative hypotheses for the explanation of differences. Acta Zoologica Academiae Scientiarum Hungaricae 42: 163-172.

Benítez-López, A., Alkemade, R. and Verweij, P.A. 2010. The impacts of roads and other infrastructure on mammal and bird populations: A meta-analysis. Biological Conservation 143: $1307-1316$

Bibby, C.J., Burgess, N.D., Hill, D.A. and Mustoe, S.H. 2000. Bird Census Techniques, 2nd ed. Academic Press, London.

BierregaArd, R.O. Jr. and Lovejoy T.E. 1989. Effects of forest fragmentation on Amazonian understory bird communities. Acta Amazonica 19: 215-241.

BlaIr, R.B. 1996. Land use and avian species diversity along an urban gradient. Ecological Applications 6: 506-519.

Brotons, L. and Herrando, S. 2001. Reduced bird occurrence in pine forest fragments associated with road proximity in a Mediterranean agricultural area. Landscape and Urban Planning 57: 77-89.

Canaday, C. 1997. Loss of insectivorous birds along a gradient of human impact in Amazonia. Biological Conservation 77: 63-77.

Carrascal, L.M., Tellería, J.L. and Valido, A. 1992. Habitat distribution of canary chaffinches among islands: competitive exclusion or species-specific habitat preferences? Journal of Biogeography 19: 383-390.

Carrascal, L.M. and Palomino, D. 2005. Preferencias de hábitat, densidad y diversidad de las comunidades de aves en Tenerife (Islas Canarias). Animal Biodiversity and Conservation 28(2): 101-119.

Cleveland, W.S., Grosse, E. and Shyu, W.M. 1992. "Local regression models," in Chambers, J.M. $\&$ Hastie, T., eds. Statistical models in S. Pacific Grove, California, Wadsworth \& Brooks/ Cole, 309-376.

Coffin, A.W. 2007. From roadkill to road ecology: A review of the ecological effects of roads. Journal of Transport Geography 15: 396-406.

Contreras, M.J. 1988. Seguimiento de los micromamiferos del P.N. de Garajonay-La Gomera. Resultados: noviembre 1987-nov.88. Informe no publicado, La Laguna. [In Spanish].

Dale, V.H., Pearson, S.M., Offerman, H.L. and O’Neill, R.V. 1994. Relating patterns of landuse change to faunal biodiversity in the Central Amazon. Conservation Biology 8: 1027-1036.

D’Amico, M., Rouco, C., Russell, J.C., Román J. and Revilla, E. 2013. Invaders on the road: synanthropic bird foraging along highways. Oecologia Australis 17(1): 86-95.

Delgado J.D., Arévalo, J.R. and Fernández-Palacios J.M. 2001. Road and topography effects on invasion: edge effects in rat foraging patterns in two oceanic island forests (Tenerife, Canary Islands). Ecography 24: 539-546. 
Delgado J.D., Arévalo, J.R. and Fernández-Palacios J.M. 2005. Patterns of artificial nest predation by exotic rats in a fragmented subtropical forest (Tenerife, Canary Islands). Journal of Natural History 38: 2661-2669.

Delgado J.D., Arévalo, J.R. and Fernández-Palacios J.M. 2007. Road edge effects on the abundance of the lizard Gallotia Gallotia (Sauria: Lacertidae) in two Canary Islands forests. Biodiversity and Conservation 16, 2949-2963.

Delgado J.D., Arroyo, N., Arévalo, J.R. and Fernández-Palacios, J.M. 2007. Edge effects of roads on temperature, light, canopy cover, and canopy height in laurel and pine forests (Tenerife, Canary Islands). Landscape and Urban Planning 81: 328-340.

Delgado J.D., Arévalo, J.R. and Fernández-Palacios J.M. 2008. Bird communities in two oceanic island forests (Tenerife, Canary Islands) fragmented by roads. Ostrich 79: 219-226.

Delgado, J.D. 2009. «Brezales macaronésicos endémicos», in VV.AA., Bases ecológicas preliminares para la conservación de los tipos de hábitat de interés comunitario en España. Ministerio de Medio Ambiente, y Medio Rural y Marino, Madrid. 62 p. [In Spanish].

Delgado J.D., Arroyo, N., Arévalo, J.R. and FernándeZ-Palacios, J.M. 2013a. Road edge effects on litter invertebrate communities of subtropical forests. Journal of Natural History 47(34): 203-236.

Delgado, J.D., Morales, G., Arroyo, N. and Fernández-Palacios, J.M. 2013b. Environmental responses of leaf litter invertebrates to road edges in subtropical island forests. Pedobiologia 56: 137-146.

Del Arco, M., González-González, R., Garzón-Machado, V. and Pizarro-Hernández B. 2010. Actual and potential natural vegetation on the Canary Islands and its conservation status. Biodiversity Conservation 19: 3089-3140.

DeGraAf, R.M. 1992. Effects of even-aged management on forest birds at northern hardwood stand interfaces. Forest Ecology and Management 46: 5-110.

Donaldson, A. and Bennett, A. 2004. Ecological effects of roads: Implications for the internal fragmentation of Australian parks and reserves. Parks Victoria Technical Series No. 12. Parks Victoria, Melbourne.

FAhrig, L. and Rytwinski, T. 2009. Effects of roads on animal abundance: an empirical review and synthesis. Ecology and Society 14(1), 21. [online] URL: http://www.ecologyandsociety. org/vol14/iss1/art $21 /$.

Fernández-Palacios, J.M. 2009. 9360 «Laurisilvas macaronésicas (Laurus, Ocotea)», in VV.AA., Bases ecológicas preliminares para la conservación de los tipos de hábitat de interés comunitario en España. Ministerio de Medio Ambiente, y Medio Rural y Marino, Madrid, 68 p. [In Spanish].

FERRIS, C.R. 1979. Effects of Interstate 95 on breeding birds in northern Maine. Journal of Wildlife Management 43: 421-427.

Forman, R.T.T. and Deblinger, R.D. 2000. The ecological road-effect zone of a Massachusetts (USA) suburban highway. Conservation Biology 14: 36-46.

Forman, R.T.T., Sperling, D., Bissonette, J.A., Clevenger, A.P., Cutshall, C.D., Dale, V.H., Fahrig, L., France, R., Goldman, C.R., Heanue, K., Jones, A.J., Swanson, F.J., TurRentine, T. and Winter, T.C. 2002a. Road ecology: science and solutions. Island Press, Washington, D.C., USA. 
Forman, R.T.T., Reineking, B. and Hersperger, A.M. 2002b. Road traffic and nearby grassland bird patterns in a suburbanizing landscape. Environmental Management 29: 782-800.

Fraser, G.S. and Stutchbury, B.J.M. 2004. Area-sensitive forest birds move extensively among forest patches. Biological Conservation 118: 377-387.

Gauch, H.G., Jr. 1982. Multivariate Analysis in Community Structure. Cambridge University Press, Cambridge.

García-Carrasco, J.-M., Tapia, W. and Muñoz. A.-R. 2020. Roadkill of birds in Galapagos Islands: a growing need for solutions. Avian Conservation and Ecology 15(1):19.

Gucinski, H., Furniss, M.J., Ziemer, R.R. and Brookes, M.H. 2001. Forest roads: a synthesis of scientific information. Gen. Tech. Rep. PNWGTR-509. Portland, OR: U.S. Department of Agriculture, Forest Service, Pacific Northwest Research Station, 103 p.

Harris, C.M. 1998. Manual de medidas acústicas y control del ruido. MacGraw-Hill, Madrid. [In Spanish].

HARRIS, L.D. 1984. The fragmented forest: island biogeography theory and the preservation of biotic diversity. University of Chicago Press, Chicago.

Havlin, J. 1987. Motorways and birds. Folia Zoologica 36: 137-153.

Heilman, G.E., Strittholt, J.R., Slosser, N.C. and Dellasala, D.A. 2002. Forest fragmentation of the conterminous United States: assessing forest intactness through road density and spatial characteristics. BioScience 52: 411-422.

Hernández, M.A., Martín, A. and Nogales, M. 1999. Breeding success and predation on artificial nests of the endemic pigeons Bolle's laurel pigeon Columba bollii and white-tailed laurel pigeon Columba junoniae in the laurel forest of Tenerife (Canary Islands). Ibis 141: 52-59.

Hill, M.O. and GaUch, H.G. 1980. Detrended correspondence analysis: An improved ordination technique. Vegetatio 42: 47-58.

Holm, T.E. and Laursen, K. 2011. Car traffic along hedgerows affects breeding success of Great Tits Parus major. Bird Study 58: 512-515.

Hunter, W.C., Buehler, D.A., Canterbury, R.A., Confer, J.L. and Hamel, P.B. 2001. Conservation of disturbance-dependent birds in eastern North America. Wildlife Society Bulletin 29: 440-455.

Jaeger, J.A.G., Bowman, J., Brennan, J., Fahrig, L., Bert, D., Bouchard, J., Charbonneau, N., Frank, K., Gruber, B. and von Toschanowitz, K.T. 2005. Predicting when animal populations are at risk from roads: an interactive model of road avoidance behavior. Ecological Modeling 185: 329-348.

Kociolek, A.V., Clevenger, A.P., St. Clair, C.C. and Proppe, D.S. 2011. Effects of road networks on bird populations. Conservation Biology 25: 241-249.

Kroodsma, R.L. 1984. Effect of edge on breeding forest bird species. Wilson Bulletin 96: 426-436.

Laurance, S.G.W. 2004. Responses of understory rain forest birds to road edges in central Amazonia. Ecological Applications 14: 1344-1357.

Laurance, S.G.W., Stouffer, P.C. and Laurance, W.F. 2004. Effects of road clearings on movement patterns of understory rainforest birds in central Amazonia. Conservation Biology 18 (4): 1099-1109.

Lindell, C.A., Riffell, S.K., Kaiser, S.A., Battin, A.L., Smith, M.L. and Sisk, T.D. 2007. Edge responses of tropical and temperate birds. Wilson Journal of Ornithology 119: 205-220. 
LynCH, J.F. and SAUnders, D.A. 1991. «Responses of bird species to habitat fragmentation in the wheatbelt of Western Australia: interiors, edges and corridors», pp 143-158, in Saunders, D.A., R.J. Hobbs (eds.), Nature Conservation 2: The role of corridors. Surrey Beatty and Sons, Sydney.

Maas, B., Putra, D.D., Waltert, M., Clough, Y., Tscharntke, T. and Schulze, C.H. 2009. Six years of habitat modification in a tropical rainforest margin of Indonesia do not affect bird diversity but endemic forest species. Biological Conservation 142(11): 2665-2671.

Magurran, A., Measuring biological diversity. Blackwell Publishing, Oxford.

Marrero, P., Cabrera, V.M., Padilla, D.P. and Nogales, M. 2010. Ecología trófica de las palomas endémicas de las Islas Canarias (Columba bollii y C. junoniae) y dispersión de semillas en la laurisilva del Parque Nacional de Garajonay (La Gomera). Proyectos de investigación en parques nacionales 2006-2009: 409-424.

Martín, A., Hernández, M.A., Lorenzo, J.A., Nogales, M. and González, C. 2000. Las palomas endémicas de Canarias. Tenerife: Consejería de Política Territorial y Medio Ambiente de Canarias, SEO-Birdlife, p. 191. [In Spanish].

Martín, A. and Lorenzo, J.A. 2001. Aves del archipiélago Canario. Francisco Lemus (Ed.). La Laguna, Tenerife, Canary Islands. [In Spanish].

McGarigal, K. and МсСомв, W.C. 1995. Relationships between landscape structure and breeding birds in the Oregon Coast Range. Ecological Monographs 65(3): 235-260.

McWethy, D.B., Hansen, A.J. and Verschuyl, J.P. 2009. Edge effects for songbirds vary with forest productivity. Forest Ecology and Management 257: 665-678.

Meunier, F.D., Verheyden, C. and Jouventin, P. 1999. Bird communities of highway verges: influence of adjacent habitat and roadside management. Acta Oecologica 20: 1-13.

Miller, J.R., Joyce, L.A., KNight, R.L. and King, R.M. 1996. Forest roads and landscape structure in the southern Rocky Mountains. Landscape Ecology 11: 115-127.

Morelli, F., Beim, M., Jerzak, L., Jones, D. and Tryjanowski, P. 2014. Can roads, railways and related structures have positive effects on birds? -A review. Transportation Research Part D Transport and Environment 30: 21-31

MosкÁt, C. and Waliczky, Z. 1992. Bird-vegetation relationships along ecological gradients: ordination and plexus analysis. Ornis Hungarica 2: 45-60.

Odum, E.P. 1971. Fundamentals of ecology. W.B. Saunders Co, Filadelfia.

Oliveira, P., Neves, H.C. and Silva, I. 1998. Composition, structure and density changes of passerine communities in Laurel Forest, exotic forest and agricultural fields on Madeira Island. Boletim do Museu Municipal do Funchal Sup. 5: 291-298.

Ortega Y.K. and Capen, D.E. 1999. Effects of forest roads on habitat quality for Ovenbirds in a forested landscape. Auk 116: 937-946.

Parris, K.M. and Schneider, A. 2008. Impacts of traffic noise and traffic volume on birds of roadside habitats. Ecology and Society 14(1), 29. [online] URL: http://www.ecologyandsociety. org/vol14/iss1/art29/.

Pearman, P.B. 2002. The scale of community structure: habitat variation and avian guilds in tropical forest understory. Ecological Monographs 72: 19-39.

Peris, S.J. and Pescador, M. 2004. Effects of traffic noise on passerine populations in Mediterranean wooded pastures. Applied Acoustics 65: 357-366. 
Reijnen, R. and Thissen, J.B.M. 1987. «Effects from road traffic on breeding-bird populations in woodland», pp. 121-132, in Annual Report 1986, Jaarverslag, Research Institute for Nature Management, Arnhem.

Reijnen, R. and Foppen, R. 1994. The effects of car trafic on breeding bird populations in woodland. Part I. Evidence of reduced habitat quality for willow warblers (Phylloscopus trochilus) breeding close to a highway. Journal of Applied Ecology 31: 85-94.

Reijnen, R., Foppen, R., Terbraak, C. and Thissen, J. 1995. The effects of car traffic on breeding bird populations in woodland. III. Reduction of density in relation to the proximity of main roads. Journal of Applied Ecology 32: 187-202.

Reijnen, R., Foppen, R. and Veenbaas, G. 1997. Disturbance by traffic of breeding birds: evaluation of the effect and considerations in planning and managing road corridors. Biodiversity and Conservation 6: 567-581.

Rich, A.C., Dobkin, D.S. and NiLes, L.J. 1994. Defining forest fragmentation by corridor width: the influence of narrow forest-dividing corridors on forest-nesting birds in southern New Jersey. Conservation Biology 8, 1109-1121.

Rittters, K.H. and Wickham, J.D. 2003. How far to the nearest road? Frontiers in Ecology and the Environment 1: 125-129.

Rolstad, J. 1991. Consequences of forest fragmentation for the dynamics of bird populations: conceptual issues and the evidence. Biological Journal of the Linnean Society 42: 149-163.

ŠáleK, M., Svobodová, J. and Zasadil, P. 2010. Edge effect of low-traffic forest roads on bird communities in secondary production forests in central Europe. Landscape Ecology 25: 1113-1124.

Santos, T., Tellería, J.L., Carbonell, R., García, F. and López, M. 1998. «Patrones de distribución de las aves en encinares fragmentados de la meseta», in Santos, T., Tellería, J.L. (eds.). Efectos de la fragmentación de los bosques sobre los vertebrados en las mesetas ibéricas. Colección Técnica, Ministerio de Medio Ambiente, Madrid. [In Spanish].

SoKal R.R. and Rohlf, F.J. 1995. Biometry. W.H. Freeman and Company, New York.

SPSS Inc. 1999. SPSS Base 10.0 for Windows User's Guide. SPSS Inc., Chicago IL.

Steadman, D.W. 2006. Extinction and biogeography of tropical Pacific birds. The University of Chicago Press.

Tejera G., Rodríguez, B., Armas, C. and Rodríguez, A. 2018. Wildlife-vehicle collisions in Lanzarote Biosphere Reserve, Canary Islands. PLoS ONE 13(3): e0192731.

Ter Braak, C.J.F. and Smilauer, P. 1998. CANOCO reference manual and user's guide to Canoco for Windows - software for canonical community ordination (version 4). Microcomputer Power, Ithaca, NY.

VAn der Ree, R., Smith, D.J. and Grilo, C. 2015. Handbook of Road Ecology. A Practitioner's Guide to Impacts and Mitigation. Wiley-Blackwell.

Watson J.E.M., Whittaker, R.J. and Dawson, T.P. 2004. Habitat structure and proximity to forest edge affect the abundance and distribution of forest-dependent birds in tropical coastal forests of southeastern Madagascar Original Research. Biological Conservation 120: 311-327.

Weiserbs, A. and JАСОB, J.-P. 2002. Does the noise due to the highway traffic influence the distribution of the breeding birds? Aves 39: 54-56.

Whitcomb, R.E., Lynch, J.E., Klimkiewicz, M.K., Robbins, C., Whitcomb, B.L. and Bystrak, D. 1981. Effects of forest fragmentation on avifauna of the eastern deciduous forest, 
pp. 25-205, In: Forest island dynamics in man-dominated landscapes (Burgess, R.L., Sharpe, D.M., eds.). Springer-Verlag, New York.

Whittaker, R.J. and Fernández-Palacios, J.M. 2007. Island biogeography: ecology, evolution, and conservation, 2nd ed. Oxford Univ. Press.

Wilcove, D.S., McLellan, C.H. and Dobson, A.P. 1986. Habitat fragmentation in the temperate zone. In: Conservation Biology: Science of Scarcity and Diversity. M. Soulé ed. Sinauer Associates, Sunderland, MA.

Willson, M.F., De Santo, T.I., Sabag, C. and Armesto, J.J. 1994. Avian communities of fragmented south-temperate rainforests in Chile. Conservation Biology 8: 508-520.

Wolf, I.D., Hagenloh, G. and Croft, D.B. 2013. Vegetation moderates impacts of tourism usage on bird communities along roads and hiking trails. Journal of Environmental Management 129: 224-234.

Yahner, R.H. 1988. Changes in wildlife communities near edges. Conservation Biology 2: 333-339. 